\title{
МОВОЮ ДОКУМЕНТІВ
}

Історико-політичні проблеми сучасного світу: Збірник наукових статей. - Чернівці:

Чернівецький національний університет, 2019. - T. 40. - C. 207-243

DOI: $10.31861 / \mathrm{mhpi} 2019.40 .207-243$

УДК: 323(477)"1914/1922"(093.2)

Modern Historical and Political Issues: Journal in Historical \& Political Sciences. - Chernivtsi: Chernivtsi National University, 2019. - Volume. 40. - pp. 207-243 DOI: $10.31861 / \mathrm{mhpi} 2019.40 .207-243$

\section{(C) Віталій Макар ${ }^{1}$ (C) Юрій Макар ${ }^{2}$ (C) Віталій Семенко ${ }^{3}$ (C) Андрій Стецюк ${ }^{4}$}

\section{Події 1914-1922 років в Україні: їх сенс та історичне значення (Частина 2)}

Редакція продовжує видання найсуттєвіших документів, які характеризують стан та поступ українського національно-визвольного руху, його бачення в інших державах на початку XX ст. Публікація вибраних документів з першого тому збірника документів «Події 1914-1922 років в Україні: їх сенс та історичне значення» була здійснена у 39-му томі Збірника. Цього разу публікуємо матеріали 3 другого тому.

Ми вибрали 10 документів, які хронологічно охоплюють час від 17 січня по 9 травня 1918 року. Вони репрезентують бачення української проблеми правлячими колами АвстроУгорщини і Німеччини, а також зусилля українських громадсько-політичних діячів, спрямовані на виборювання незалежності України, відтворюють атмосферу переговорів у Брест-Литовську.

Перші чотири документи - австрійські проекти імперського маніфесту з нагоди мирного договору з Україною і протоколи зустрічей німецької, австрійської та української делегацій під час підготовки мирного договору. П'ятий - текст Брест-Литовського мирного договору від 9 лютого 1918 р. Наступні п’ять документів характеризують ставлення радянської Росії та Польщі до положень Договору, а також Німеччини щодо державної належності Холмщини. Сподіваємося дані документи стануть у нагоді як студентам, так і дослідникам міжнародних відносин і історії України початку XX ст.

Оскільки документи вибрані нами з різних частин книги, ми як раніше зберегли їх порядкові номери та номери сторінок, стилістику оформлення заголовків та підписів. Також подаємо перед ними список скорочень другого тому в оригіналі.

Ключові слова: Австро-Угорщина, Брест-Литовський мир, Галичина, Німеччина, Україна, Українська Народна Республіка, український національний рух, українці, Холмщина.

\section{Events in Ukraine 1914-1922 Their Importance and Historical Background (Part II)}

The editorial board continues to publish the most significant documents, which characterize the status and progress of the Ukrainian national liberation movement, its vision in other countries in the early 20th century. The documents from the first book «Events in Ukraine 1914-1922 their

\footnotetext{
${ }^{1}$ Кандидат політичних наук, доцент кафедри міжнародних відносин, директор Центру канадських студій Чернівецького національного університету імені Юрія Федьковича, Україна. E-mail: vit_makar@yahoo.com; https://orcid.org/0000-0001-8994-4582.

2 Доктор історичних наук, професор, заслужений діяч науки і техніки України, завідувач кафедри міжнародних відносин Чернівецького національного університету імені Юрія Федьковича, Україна. E-mail: y.makar@chnu.edu.ua; https://orcid.org/0000-0002-7904-828X.

${ }_{3}^{3}$ Кандидат політичних наук, доцент кафедри сучасних іноземних мов та перекладу Чернівецького національного університету імені Юрія Федьковича, Україна. E-mail: v.semenko@chnu.edu.ua; https://orcid.org/0000-0002-4353-7823.

4 Кандидат політичних наук, доцент кафедри міжнародних відносин Чернівецького національного університету імені Юрія Федьковича, Україна. E-mail: a.stetsyuk@chnu.edu.ua; https://orcid.org/0000-00022948-7161.
} 
importance and historical background» were published in Volume 39 of the Scientific journal. We publish the papers from the second book in current volume.

We have selected 10 documents that chronologically cover the period from January 17 to May 9 , 1918, and reproduce the vision of the Ukrainian problem by the ruling circles of Austro-Hungarian Empire and Germany, as well as the efforts of Ukrainian public-political figures aimed at the election of Ukraine's independence, reproduce the atmosphere of negotiations in Brest-Litovsk.

The Austrian drafts of the imperial manifesto on the occasion of the peace treaty with Ukraine and the protocols of meetings of the German, Austrian and Ukrainian delegations during the preparation of the peace treaty are presented as the first 4 documents. The text of the Brest-Litovsk Peace Treaty signed on 9February, 1918 is the fifth document. The following five documents characterize the attitude of Soviet Russia and Poland to the provisions of the Treaty, as well as Germany's attitude to the state affiliation of the Kholmshchyna. These documents will be useful for both students and researchers of international relations and history of Ukraine in the early 20th century.

Whereas we have selected documents from different parts of the book, we stored their serial numbers. Page numbers are shown in square brackets after the text. The language, style of the headings and captions, cursive and text selection are all preserved. Also, for convenience of possible use by interested persons, we submit to them a list of abbreviations from the second book in the original.

Keywords: Austro-Hungarian Empire, Brest-Litovsk peace treaty, Galicia, Germany, Ukraine, The Ukrainian People's Republic, Ukrainian national movement, Ukrainians, Kholmshchyna.

Відповідно з прийнятим рішенням продовжуємо публікацію, за цим разом, матеріалів 3 другого тому німецькомовних документів «Події 1914-1922 років в Україні: їх сенс та історичне значення» (Hornykiewicz Theophil. Events in Ukraine 1914-1922 their importance and historical background / Publications of the W. K. Lypynsky east european research institute. - Volume I. - Philadelphia, 1967. - XLVIII, 484 р.) стосовно українського питання під час і після Першої світової війни.

Удругому томі томі видання зібрані і згруповані у хронологічному порядку в 10 рубриках (остання поділена на 5 частин) 293 документа (іх нумерація продовжуються від першого тому), які охоплюють період з 28 лютого 1914 р. по 23 жовтня 1918 р.:

1. 170-221: FRIEDENSVERTRAG MIT DER UKRAINE (1917.IV.12. - 1918.II.28.);

2. 222-245: PROTOKOLLE DER BRESTER FRIEDENSVERHANDLUNGEN ZWISCHEN DEN DELEGIERTEN DER VERBÜNDETEN MÄCHTE UND DEN UKRAINISCHEN UND RUSSISCHEN DELEGIERTEN; JÄNNER BIS FEBRUAR 1918 (1918.I.4. - 1918.II.9.);

3. 246-295: AUFREGUNG IN POLEN WEGEN ANGLIEDERUNG CHOLMS AN DIE URKAINE (1918.II.10. - 1918.V.9);

4. 296-311: ABÄNDERUNG DES ARTIKELS II, Punkt 2, DES BRESTER FRIEDENSVERTRAGES (CHOLMERFRAGE) GEGEN ZUSICHERUNG DER MILITÄRHILFE FÜR DIE UKRAINE SEITENS DER ZENTRALMÄCHTE (1918.II.11. - 1918.IV.2.);

5. 312-338: VERSUCHE DER UKRAINISCHEN REGIERUNG, DIE VERWALTUNG DES CHOLMER GEBIETES IN DIE HAND ZU NEHMEN (1918.II.24. - 1918.X.23.);

6. 339-367: SCHUTZ DER POLNISCHEN GROSSGRUNDBESITZER IN DER UKRAINE (1918.1.19. - 1918.V.4.);

7. 368-397a: BEMÜHUNGEN UM DIE RESTITUIERUNG DER GR.-KATH. DIÖZESE CHOLM (1915.X.31. - 1918.X.10.);

8. 398-406: BEMÜHUNGEN DER ORTHODOXEN HIERARCHIE, IN DAS CHOLMERLAND ZURÜCKZUKEHREN (1918.VIII.26. - 1918.X.21.);

9. 407-417: NOTENWECHSEL BETREFFEND DIE ÜBERFÜHRUNG DER RELIQUIEN DES HL. JOSAPHAT KUNCEWYCZ AUS BIALA NACH ÖSTRREICH (1916.1.17. - 1916.V.24.);

10. [418-461] GR.-KATH. ERZBISCHOF VON LEMBERG UND METROPOLIT VON HALYCZ ANDREAS-ALEXANDER GRAF SZEPTYCKYJ - KARDINALSKANDIDAT, GEFANGENER IN RUSSLAND, VORKÄMPFER DER UNION:

- 418-432: VORSCHLÄGE DER K. U. K. REGIERUNG ÜBER DIE VERLEIHUNG DER KARDINALSWÜRDE (1914.II.28. - 1916.XII.1.);

- 433-440: ERZBISCHOF UND METROPOLIT GRAF SZEPTYCKYJ - GEFANGENER IN RUSSLAND (1914.VIII.25. - 1917.VI.11.); 
- 441-445: TÄTIGKEIT DES ERZBISCHOFS UND METROPOLITEN SZEPTYCKYJ FÜR DIE UNION MIT ROM (1917.V.24. - 1917.VIII.13.);

- 446-455: RÜCKKEHR DES ERZBISCHOFS SZEPTYCKYJ AUS DER GEFANGENSCHAFT IN RUSSLAND (1917.VII.10. - 1917.VIII.26.);

- 456-461: VERLEIHUNG DES GROSSKREUZES DES LEOPOLD-ORDENS MIT DER KRIEGSDEKORATION AN DEN GR.-KATH. ERZBISCHOF UND METROPOLITEN ANDREAS GRAFEN SZEPTYCKYJ (1917.VIII.24. - 1917.VIII.27.)

Це документи що зберігаються у Державному архіві Австрії - листування військовополітичного керівництва Австро-Угорщини та Німеччини під час Першої світової війни, різноманітні звернення українських державно-політичних діячів стосовно української державності, приналежності до України тих, чи інших українських етнічних земель тощо. Документи другого тому охоплюють зокрема і питання взаємин урядів УНР та Гетьманату з іншими державами, підготовки, узгодження та підписання Брест-Литовського мирного договору 1918 р., тлумачення його окремих статей, державної належності Холмщини, тощо. Значна увага приділяється діяльності Митрополита Галицького та Архієпископа Львівського Андрея Шептицького. Як і в першому томі, наприкінці поміщено іменний, термінологічний та географічний показчики 6 .

3 другого тому ми вибрали для публікації 10 документів, які хронологічно охоплюють час від 17 січня по 9 травня 1918 року і відтворюють атмосферу переговорів у Брест-Литовську:

- 2 австрійські проекти імперського маніфесту з нагоди мирного договору з Україною (документи 215-216);

- 2 протоколи зустрічей німецької, австрійської та української делегацій від 17 і 19 січня, на яких обговорювалися питання про державну належність та статус Холмщини, Східної Галичини і північної Буковини, права національних меншин і укладення торгівельної угоди (233-234);

- текст Брест-Литовського мирного договору 9 лютого 1918 р. (244);

- протокол засідання Політичної комісії німецької, австрійської та російської делегацій від 9 лютого 1918 р. із запереченнями Л.Троцького щодо укладення мирного договору з УНР (245);

- документи від 10, 11 i, ймовірно, 11/12 лютого, що засвідчують реакцію Польщі на БрестЛитовський мир (246, 250, 251);

- реакція Німеччини на брошуру Георга фон Гассенка «Холмщина польська чи українська?» та її текст (295).

Сподіваємося дані документи стануть у нагоді як студентам, так і дослідникам міжнародних відносин і історії України початку XX століття.

Провідне місце у другому томі займає Берестейський мирний договір з Україною від 9 лютого 1918 року, а також питання, пов'язані з ним. Це, на думку укладача Теофіла Горникевича, цілком виправдано, адже укладення Мирного договору між УНР і Четверним союзом належить до найзначніших подій Першої світової війни. Як вважав Т. Горникевич, Берестейський мирний договір мав першорядне значення, особливо для історії України. Після тривалого іноземного панування Україна досягла визнання політичної незалежності.

Більше того, Берестейський мирний договір важливий ще й з іншої причини. Для того, щоб його належним чином оцінити, необхідно враховувати ситуацію усіх воюючих держав на той час, але перш за все Австро-Угорщини та Німеччини. Триваюча війна з їі людськими і матеріальними втратами надмірно обтяжила усі верстви населення цих двох держав. Військова потужність Німеччини, тим більше Австро-Угорщини, вичерпалася. Перш за все, населення найбільших міст потерпало від нестачі продуктів харчування, що викликало невдоволення і навіть виступи проти влади. 12 квітня 1917 року міністр закордонних справ Австро-Угорщини, граф Оттокар Чернін повідомив імператора, що ситуація настільки напружена, що можна очікувати на вибухи невдоволення будь-коли. Далі О. Чернін висловив сумнів, «що внутрішня ситуація в

\footnotetext{
${ }^{5}$ Hornykiewicz T. (1967), Events in Ukraine 1914-1922 their importance and historical background, Publications of the W. K. Lypynsky east european research institute, Philadelphia, Vol. II, pp. 1-453.

${ }^{6}$ Ibid., pp. 454-484.
} 
Німеччині могла бути кращою...» $\rangle^{7}$ За його словами, монархи Центральних держав повинні негайно укласти мир, бо в іншому випадку це зроблять народи понад їхні голови» ${ }^{8}$. На думку ж Т. Горникевича укладення миру для початку хоч би з УНР створювало не тільки можливість порятунку від голоду, але й усувало загрозу державному суверенітетові. Навіть перспектива укладення миру на Східному фронті, з військової точки зору, забезпечувала Центральним державам, особливо Німеччині можливість перевести війська, що тут воювали, на Західний фронт, що могло значно поліпшити їі становище. 5 грудня 1917 року делегація Четверного союзу з перемир'я розпочала переговори у Берестейській фортеці, а через десять днів підписала перемир'я з радянською Росією.

А 16 грудня, як відомо, до Берестя прибули представники Української Центральної Ради і вимагали від російської більшовицької делегації згоди на участь у підписанні договору про припинення вогню, як і для участі в майбутніх мирних переговорах загалом.

Поява незалежної української делегації неохоче сприйнялась представниками Центральних держав, а з іншого боку, це означало довгоочікуване послаблення російської делегації під час майбутніх мирних переговорів. Таким чином, перед Центральними державами з'явилася перспектива швидкого просування переговорів, принаймні, з одним із контрагентів для укладення мирного договору.

Представники Центральних держав провели декілька попередніх зустрічей з українською делегацією. Вони також сприйняли офіційну ноту Генерального секретаріату від 24 грудня 1917 року про виняткову прерогативу Центральної Ради щодо здійснення суверенних прав на території України і ії прагнення до загального миру. Після цього на пленарному засіданні 12 січня 1918 року О. Чернін зробив офіційну заяву, що Четверний союз визнає «українську делегацію як самостійну делегацію і як повноважне представництво проголошеної Української Народної Республіки. Формальне визнання Української Народної Республіки як самостійної держави чотирма союзними державами залишається за мирним договором» ${ }^{9}$. В завуальованій формі це підтвердив і Лев Троцький. Однак його заява виявилася тактичним маневром, бо після прибуття до Берестя представників Народного секретаріату з Харкова, учасник російської делегації Адольф Йоффе звернувся до делегації Центральних держав, що власне вони мають представляти Україну у складі російської делегації. Відповідну позицію зайняв і Л. Троцький.

Між тим стало зрозумілим, що російська делегація не дуже поспішала з укладенням мирного договору з державами Четверного союзу. О. Чернін 13 січня 1918 року заявив, що «тактика російської делегації полягає на тому, щоб затягувати переговори і створювати завдяки цьому в нашому тилу занепокоєння. Для мене безсумнівно зрозуміло, що у більшовиків є таємні стосунки 3 нашими соціалістами» ${ }^{10}$.

Враховуючи намагання російської делегації щодо затягування переговорів перспектива швидкого досягнення миру для країн Четверного союзу втрачала сенс. Ця обставина сприяла готовності чотирьох держав до переговорів з представниками Центральної Ради, вимоги з боку якої зводилися до:

• визначення північно-західного кордону Української держави з включенням до іï складу Холмщини;

- забезпечення політичних прав українців, які проживають в Австро-Угорщині;

- створення особливих комісій, які проводитимуть обмін полоненими, інвалідами, хворими і т. д.;

- опрацювання Торгівельної угоди між Центральними державами та Україною.

Перші дві вимоги української делегації відверто суперечили «австро-польському рішенню», згідно з яким до Польщі мали відійти Холмщина і вся Галичина. Українська ж делегація вимагала визнати право на самовизначення для українців, які проживали у Східній Галичині та Холмщині.

\footnotetext{
${ }^{7}$ Тут і далі цитуємо за: Hornykiewicz Т. (1967), Aus dem Inhalt des II. Bandes, Events in Ukraine 1914-1922 their importance and historical background, Publications of the W. K. Lypynsky east european research institute, Philadelphia, Vol. II, p. XXXI.

${ }^{8}$ Ibid, p. XXXI-XXXII.

${ }^{9}$ Ibid, p. XXXIII.

${ }^{10}$ Ibid.
} 
Враховуючи прямо протилежні вимоги $з$ українського і польського боків з цього питання, перспектива для чотирьох держав укласти мирний договір, принаймні, з Україною, виглядала не дуже реальною. Однак тоді обидві сторони перебували під впливом загрозливих подій у власному тилу, що змушувало їх до поміркованості у тактиці веденні переговорів. Саме в цей час у Відні та в інших великих містах Австро-Угорської монархії спалахнула гостра криза. Вимоги «хліба і швидкого миру» ставали все голоснішим всюди, зокрема завдяки лівим елементам, які висували лозунги з закликами до революції.

На території України діяли більшовицькі війська на чолі з Михайлом Муравйовим, головною метою якого було захоплення Києва, де перебувала Українська Центральна Рада.

Все це змушувало Четверний союз і Центральну Раду проявити готовність до компромісу. Українська делегація зняла вимогу про право на самовизначення українців, які проживали у Східній Галичині, але зажадала створення особливого коронного краю, що складався із Східної Галичини і Буковини. О. Чернін через насування «голодної революції» у власній країні, був схильний укласти ще дуже сприятливий для України мирний договір, прагнучи, однак, з політичних причин зберегти польські інтереси в Україні.

Таким чином, після кількох зустрічей між німецькою, австро-угорською та українською делегаціями між 13 і 19 січня 1918 року було досягнуто згоди щодо вирішення питання Східної Галичини і Холмщини, що відповідало б українським побажанням.

Однак виконання поступок на користь УНР змусило Центральні держави враховувати щонайменше три умови:

- остаточно Мирний договір слід було укласти не пізніше 15 лютого 1918 року;

- між Центральними державами та Україною належало укласти Торгівельну угоду і після укладення миру негайно слід було розпочати ії виконання;

- в Україні полякам належало забезпечити належний культурний та національний розвиток.

Українські делегати не погоджувались включати до питань Мирного договору названі умови, посилаючись на конституційну автономію в Українській державі для всіх національних меншин, згідно з якою польські справи мали управлятися відповідним міністром і Радою представників польського суспільства в Україні.

Розробка Торгівельної угоди між Четверним союзом і Україною також викликала певні труднощі, оскільки представники Центральних держав прагнули до відновлення договору, укладеного ще 3 царською Росією. Але в умовах, що склалися, вони повинні були рахуватися з новими реаліями України.

У зв'язку з тим, що мирні переговори Центральних держав 3 представниками Центральної Ради наближалися до закінчення, Л. Троцький зробив ще одну спробу втрутитися у їх перебіг, яку однак відбив Олександр Севрюк, який власне очолював делегацію УНР на пленарному засіданні 1 лютого 1918 року.

На прохання делегації Центральної Ради О. Чернін зробив офіційну заяву на цьому ж засіданні від імені делегатів Четверного союзу, в яких УНР була визнана суверенною державою 3 правом самостійно укладати міжнародні договори. Це, по-перше, це формувало для Четверного союзу правову підставу для укладення Мирного договору з Україною, а по-друге, задовольняло вимогу представників Центральної Ради в питанні офіційного визнання суверенітету Української держави, закріплене Декларацією Четверного союзу 12 січня 1918 року, відповідно після укладання Мирного договору.

Австро-Угорщині і Німеччині потрібно було отримати з України зерно, щоб заспокоїти потреби своїх громадян у хлібі. Зокрема, 7 лютого 1918 року Фрідріхом Візнером, представником Четверного союзу, і Миколою Любинським, представником УНР, був підписаний протокол, у якому українська сторона зобов'язалася в найкоротший термін поставити не менше мільйона тонн зерна. Ф.Візнер додав до протоколу декларацію, за якою від виконання цього зобов'язання залежала ратифікація Мирного договору. Хоча українські делегати взяли до уваги цю заяву, вони відмовилися підписати її з внутрішніх політичних міркувань.

Після того як українська сторона взяла на себе важкі економічні зобов'язання по відношенню до Центральних держав, 8 лютого 1918 року було підписано таємну угоду між Австроугорською і Українською сторонами, в якій перша зобов'язалася створити зі Східної Галичини та Північної Буковини Автономний український коронний край до 20 липня 1918 року. Ця уго- 
да також містила положення про національний та культурний розвиток польської, німецької та єврейської національностей в Україні.

Вранці 9 лютого 1918 року на урочистому пленарному засіданні було підписано Берестейський мирний договір між делегацією Четверного союзу та УНР.

Того ж дня, на засіданні політичної комісії німецької, австро-угорської та російської радянської делегацій Л. Троцький рішуче виступив проти укладення Мирного договору Центральних держав з владою УНР, і заявив, що цей договір «не може мати ніякої ваги для українського народу і Російського уряду» ${ }^{11}$. Однак аргументи Л. Троцького були відхилені делегатами Четверного союзу. Річард Кюльманн, головуючий цієї сесії, спирався на автентичні новини, які спростовували твердження Л.Троцького про повалення Центральної Ради. Після невдалих спроб не допустити підписання Мирного договору УНР з Четверним союзом російський радянський уряд намагався принаймні домогтися визнання Харківського радянського Народного секретаріату Четверним союзом. 3 цією метою його делегацію, очолювану Володимиром Затонським, було надіслано до Берестя. Делегації Центральних держав категорично виступили проти допущення делегатів харківської «влади» до підписання Берестейського мирного договору спільно 3 делегацією УНР.

О. Чернін, поставивши свій підпис під таємним договором від 8 лютого 1918 року і Мирним договором від 9 лютого 1918 року, розумів, які наслідки цього акту можуть бути для АвстроУгорщини. Про них він говорив під час берлінських дискусій ще 5 лютого 1918 року: «..Якщо Холмщині довелося б відійти [до України - авт.], це означало для монархії [Австро-Угоршини - aвm.] надзвичайно велику жертву, бо тим самим австро-польські стосунки стали б під загрозою. Створення ж “української провінції східної Галичини” також вимагало усвідомлення, що цей захід може... принести небажані проблеми. Однак цю дуже серйозну жертву довелося зробити, тому що Центральні держави не змогли б дожити до нового врожаю без зовнішньої допомоги...» ${ }^{12}$.

Передбачувані О.Черніним наслідки Берестейського мирного договору з Україною не дали на себе довго чекати. Включення Холмщини, яку поляки вважали своєю територією, до України, закріплене в Мирному договорі без консультацій з поляками, викликало їх обурення. Вже 10 лютого 1918 року Стефан Угрон, представник Австро-Угорщини у Варшаві повідомив МЗС про конфіденційні зустрічі з польськими регентами, які назвали цей акт четвертим поділом Польщі.

Польська Регентська рада звернулася 16 лютого 1918 року щодо питання Холмщини безпосередньо до австро-угорського імператора. У зверненні зокрема писалося, що «інформація про Мирний договір, який було укладено з Українською Народною Республікою, вразила увесь польський народ... Хіба це не велика помилка з історичних, релігійних та культурних причин i, отже, політична помилка? Цей акт стосовно поляків здійснив міністр закордонних справ Вашої Величності» ${ }^{13}$.

Під тиском Польщі щодо статей Мирного договору з Україною, що стосувалися питання Холмщини, О. Чернін вирішив внести істотну поправку до нього на користь Польщі. Йому допомогло у цьому критичне становище в Україні. Політична і військова ситуація Центральної Ради не була стабільною. В Україні поширювався проросійський рух, більшовицькі війська увірвалися до Києва, битви точилися у центрі міста. Частина Центральної Ради вже переїхала до Житомира. 11 лютого 1918 року О.Севрюк попросив прямої допомоги Україні з боку Центральних держав.

Обставини змушували Центральну Раду прийняти вимоги О.Черніна. У результаті у Відні підписаний О. Севрюком і Ф. Візнером Протокол, в якому О. Севрюк погодився в обмін на військову допомогу Україні з боку Центральних держав та задля порятунку УНР:

a) надійно дотримуватися українською делегацією Декларації про створення окремого Східногалицького коронного краю;

b) видати протокольну заяву щодо тлумачення пункту 2 статті II Мирного договору стосовно Холмщини для публікації.

\footnotetext{
${ }^{11}$ Hornykiewicz T. (1967), Aus dem Inhalt des II. Bandes, p. XXXVII.

${ }^{12}$ Ibid, p. XXXVIII.

${ }^{13}$ Ibid, p. XXXIX.
} 
Про це О. Чернін повідомив австрійському представникові Олександрові Лаго у Варшаві: «...Після тривалих переговорів 3 представниками України, мені вдалося досягти змістового тлумачення статті II Берестейського договору в сенсі польських побажань...» ${ }^{14}$. Пізніше, 4 березня 1918 року у спеціальному додатковому протоколі до Мирного договору делегати чотирьох держав та УНР підписали спільну заяву про тлумачення пункту щодо Холмщини.

Загалом давно і добре відомо, що сталося століття тому з Берестейським мирним договором. За нинішніх обставин влада незалежної України повинна докласти усіх зусиль, щоб зберегти суверенітет на теренах, які тепер складають іiі територіальну цілісність, визнану світовим співтовариством.

Оскільки публіковані документи вибрані нами з різних частин книги, ми зберегли їх порядкові номери. Номери сторінок вказані в квадратних дужках після відповідного тексту. Мова, стилістика оформлення заголовків та підписів, курсив та виділення тексту зберігаються. Також, для зручності можливого їх використання зацікавленими особами подаємо перед ними список скорочень другого тому в оригіналі.

A. i. f. $=$ Armee im Felde

\section{Abkürzungen}

Allg. Ukr. N-Rat = Allgemeiner Ukrainischer Nationalrat

$\mathrm{AK}=$ Armeekommando

AOK $=$ Armee-Oberkommando

AVA $=$ Allgemeines Verwaltungs-Archiv

Bund z. B. d. U. = Bund zur Befreiung der Ukraine

$\mathrm{BvG}=$ Bevollmächtigter General

EOK = Etappen-Oberkommando

DOHL $=$ Deutsche Oberste Heeres-Leitung

G-L $=$ Geheim-Liasse

Gstb $=$ Generalstab

HHSt.A. = Haus-Hof und Staatsarchiv

HGKdo(HGK) $=$ Heeres-Gruppen-Kommando

K. P. Q. = Kriegs-Presse-Quartier

$\mathrm{Kr} .=$ Krieg

Kr. A. = Kriegs-Archiv

Krgf. = Kriegsgefangene

K. u. k. Min. d. Äußern = K. u. k. Ministerium des Äußern

L. Päpstl. Stuhl = Liasse Päpstlicher Stuhl

L-T. Abg. = Land-Tagsabgeordneter

O. H. L. = Oberste Heeres-Leitung

Op. A. = Operations-Abteilung

Op. N. = Operations-Nummer

Österr.-ung. = Österreichisch-ungarisch

Poln. $=$ Polnisch

Pr-L. = Presse-Leitung

Q.Abt. = Quartiermeister-Abteilung

R-R. Abg. $=$ Reichsratsabgeordneter

Russ. $=$ Russisch

Russl. = Rußland

T-S. $=$ Telegrammen-Sammlung

Ukr. A. = Ukraine-Akten

Ukrain. $=$ Ukrainisch

Ukr. Parl. Vertr. = Ukrainische Parlamentarische Vertretung

Ukr. V-Rep. = Ukrainische Volks-Republik (U. N. R.)

W-Ukr. V-Rep. = West-Ukrainische Volks-Republik

[XLVIII]

${ }^{14}$ Hornykiewicz T. (1967), Aus dem Inhalt des II. Bandes, p. XL. 
Wien, 10. Februar 1918

Das k. u. k. Min. d. Äussern an Czernin: Text des von Dr. Seidler ausgearbeiteten Entwurfes eines kaiserlichen Manifestes anläßlich des Friedensvertrages mit der Ukraine.

HHSt.A. P.A. 1056 Kr. 70/6 Konzept.

Telegramm in claris No 309

K. u. k. Ministerium des Äussern an Graf Ottokar Czernin, Brest-Litowsk. Wien, 10. Februar 1918.

Der k. k. Ministerpräsident ist von Sr. Majestät beauftragt worden, anläßlich des Friedensschlusses mit der Ukraina im Einvernehmen mit dem k. ung. Ministerpräsidenten und dem k. u. k. gemeinsamen Finanzminister den Entwurf eines Allerhöchsten Manifestes auszuarbeiten und denselben Sr. Majestät bei der morgen abends erfolgenden Allerhöchsten Rückkehr vorzulegen.

Diesem Allerhöchsten Auftrage nachkommend hat Dr. von Seidler den nachstehenden Entwurf ausgearbeitet. Er ersucht mich, denselben Euer Exzellenz behufs allfälliger Stellungnahme zu übermitteln.

Text des Entwurfes:

„Durch den Willen des Allmächtigen mitten in den Stürmen des Krieges zu Meinem hehren Amte berufen, habe Ich Mir vor allem das Ziel gesteckt, Meinen Völkern sobald als möglich einen Frieden zu gewinnen, der uns und unseren Verbündeten Ehre, Bestand und Freiheit der Zukunftsentwicklung verbürgt. Dieses Ziel galt es zu erreichen mit der Schärfe des Schwertes und mit den Mitteln der Verständigung. Unseren Feinden musste die Unbeugsamkeit unseres Widerstandes unwiderleglich bewiesen werden; zugleich aber musste wieder der Geist der Versöhnlichkeit zum Durchbruche kommen, der allein der zerrissenen Welt die Voraussetzungen eines neuen gedeihlichen Lebens zu bieten vermag. Der Herr hat unsere Waffen gesegnet; die verbündeten Heere stehen siegreich in Feindesland. Aber so oft die verbündeten Mächte in feierlichen Kundgebungen den Gedanken der Versöhnlichkeit anklingen liessen, stiess dieses Beginnen auf eine schroffe Zurückweisung seitens des Gegners. Die verbündeten Herrscher blieben fest bei dem Worte, das sie ihren Völkern für die Erreichung eines ehrenvollen Friedens, den feindlichen aber für eine redliche Verständigung gegeben haben. Einstweilen aber hiess es trotz aller Bedrängnis der Zeit an der Front wie im Hinterlande mutig und geduldig auszuharren. Meine tapferen Truppen, Meine treuen Völker haben dies wahrlich getan. Ich danke ihnen und der Herr wird es ihnen lohnen.

Nun scheint die Zeit anzubrechen, in der die verbündeten Herrscher ihr Wort Schritt für Schritt werden einlösen können. Die angestammte Gewalt, die die ungeheueren friedlich gesinnten Völkerschaften des weiten Russland beherrschte und sich zu dem unseligen Versuche verleiten liess, ihre reichen Kräfte in eine Spitze des Hasses gegen uns und unsere Verbündeten zusammenzufassen, hat diesen Mißbrauch einer von Gott verliehenen Macht mit ihrem Verfalle gebüsst. Aus den Trümmern ihrer Herrschaft wollen neue Staaten erstehen, die sich frei machen von den Sinnlosigkeit feindseliger Vorurteile und einer dieser Staaten hat mit den Mittelmächten Frieden geschlossen. Die eiserne Kette, die die Feinde in einer Politik unbegreiflichen Hasses um die Reiche des Vierbundes zu schmieden suchten, ist an einem Punkte gesprengt, die blutige Demarkationslinie, die die unglückliche Welt in zwei feindliche Waffenlager trennt, an einer Stelle ausgetilgt und über ihre verwischten Spuren hinweg werden wieder die tausendfältigen kulturellen und wirtschaftlichen Beziehungen gesitteter Völker einsetzen.

Von aufrichtiger Achtung für eine aufstrebende Nation erfüllt, von der ein namhafter Teil zu den treuesten Söhnen der Monarchie zählt, reichen wir mit herzlicher Genugtuung der Ukraina die Freundeshand.

Wir werden es nicht vergessen und sicher auch die Ukrainer nicht, daß zugleich mit dem Leben des jungen Staates auch das freundnachbarliche Verhältnis zu uns und unseren Verbündeten begonnen hat. Für Meine Völker und für die ganze Welt, auch für die unter den Leiden des Krieges in gleicher Weise seufzenden Bürger der feindlichen Staaten ist damit der die blutigste Lüge dieses Krieges widerlegende Beweis erbracht, daß es die Möglichkeit einer Verständigung gibt. Es ist aber auch ein Be- 
weis, der eine andere nicht minder tückische und friedenhemmende Lüge zerstört, ein Beweis dafür, daß die Mächte des Vierbundes die Verständigung ehrlich wollen und daß sie derjenige mit ihnen finden kann, der ihnen mit dem gleichen redlichen Willen entgegenkommt.

Kein sterbliches Auge vermag die Wege klar vorherzusehen, auf denen die Vorsehung die leidende Menschheit aus den Greueln dieses Krieges herausführen wird. Aber mit voller Gewissheit darf man sich sagen, daß das Ereignis von Brest Litowsk ein bedeutungsvoller Markstein auf diesem Wege ist.

Darum heissen Ich und die Kaiserin, in tiefer Dankbarkeit für die gnadenvolle Fügung des Allmächtigen, inmitten Unserer geliebten Völker und in einem Pulsschlag des freudig bewegten Herzens mit ihnen vereint diese erste Friedensbotschaft willkommen. Die verbündeten Mächte wollen auf der erfolgreich betretenen Bahn entschlossen weiterschreiten, den Frieden gegen die zu erzwingen, die ihn haßerfüllt verweigern, die Hand der Versöhnung aber denjenigen zu bieten, die gleich uns dazu bereit sind. Meine geliebten Völker aber werden die letzte Spanne der schweren Zeit, gestärkt durch die frohe Kunde vom 9. Februar und das Auge fest auf die am Rand aufschimmernde Morgenröte schönerer Tage gerichtet, mutig und siegreich überwinden.

Das walte Gott!

Laut einer telephonischen Mitteilung des Ministerratspräsidiums (Hofrat Übelhör) wird Dr. Wekerle heute in Budapest das Manifest Sr. Majestät unterbreiten. Nach Rücksprache mit Dr. Wekerle hat Dr. von Seidler im 3. Absatz des Manifestes den Satz: „Wir werden es nicht vergessen... begonnen hat" ausgelassen.

Auch hat sich Dr. Wekerle dafür ausgesprochen, im letzten Absätze die Worte... und die Kaiserin auszulassen. Die diesbezügliche Entscheidung ist Sr. Majestät überlassen worden.

Walterskirechen 10. 2. 1918.

Das k. u. k. Min. d. Äussern an Czernin: Text des von Dr. Wekerle ausgearbeiteten Entwurfes eines kaiserlichen Manifestes anläßlich des Friedensvertrages mit der Ukraine.

HHSt.A. P.A. 1056 Kr. 70/6 Konzept.

Hughes Telegramm in Claris No 310.

K. u. k. Ministerium des Äussern an Graf Cernin, Brest. Wien, 11. Februar 1918.

Ministerpräsident Dr. Wekerle gleichfalls von Seiner Majestät beauftragt Manifest auszuarbeiten beabsichtigt morgen nachstehenden Entwurf Seiner Majestät bei Allerhöchstderen Durchreise in Budapest zu unterbreiten. Bewusster Text lautet:

„An Meine Völker!

Wir haben mit der Ukraine Frieden geschlossen.

Unsere siegreichen Waffen und die mit unverdrossener Ausdauer verfolgte aufrichtige Friedenspolitik haben die erste Frucht des um unser Sein gefochtenen Verteidigungskampfes gezeitigt.

Im Vereine mit Meinen schwererprobten Völkern vertraue Ich darauf, daß dem ersten Sonnenstrahle, welcher die nunmehr seit 3 1/2 Jahren auf der Welt lastende Nacht zerreisst, in Bälde der Augenblick folgen wird, in welchem vom unbewölkten Himmel die Sonne des Weltfriedens die leidende Menschheit grüßt.

Unter dem Eindrucke des mit der Ukraine geschlossenen Friedens wendet sich Unser Blick voll Sympathie nach jenem strebsamen, seine Zukunft zielbewußt vorbereitenden jungen Volke, in dessen Herzen zuerst das Gefühl der Nächstenliebe erwacht ist und das in richtiger und nüchterner Beurteilung eben dieser seiner Bestrebungen und seiner Zukunft, gleichsam in Ergänzung der in zahlreichen Schlachten bewiesenen Tapferkeit, auch dazu genügend Mut fand, um seiner besseren Überzeugung offenkundig und durch die Tat Ausdruck zu verleihen und als erstes aus dem Lager unserer im blutdürstigen Hasse verblendeten, unversöhnlichen Feinde ausschied, um im Interesse der ehetunlichen Verwirklichung des nunmehr gemeinsamen großen Zieles seine Bestrebungen mit unserer Kraft zu vereinen. 
Dieses Ziel ist - wie freudig wir auch den ersten Friedensherold begrüßen mögen — leider noch nicht erreicht und wenn sich die Reihen unserer Feinde auch gelichtet haben, so hat ihr Haß der besseren Einsicht noch nicht den Platz geräumt.

Gleichwie Ich Mich von jenem Momente an, in welchem Ich den Mir von Meinen erlauchten Vorfahren vererbten Thron bestiegen, mit Meinen Völkern in jenem felsenfesten Entschlusse eins gefühlt habe, den uns aufgedrängten Kampf bis zur Erreichung eines ehrenhaften Friedens auszufechten, so fühle ich Mich mit Meinen Völkern eins auch in jener Stunde, in welcher der erste Schritt zur Verwirklichung dieses Zieles geschehen.

Mit Bewunderung und voll Anerkennung für die übermenschliche Ausdauer und unvergleichliche Opferfreudigkeit Meiner heldenhaften Truppen, sowie mit tiefempfundener glühender Liebe für Meine Völker

im Herzen, blicke Ich dankerfüllt und voll Zuversicht in eine nahe glückliche Zukunft!

Der Allmächtige segne sie mit Kraft und Ausdauer, auf daß wir nicht nur für uns und unsere treuen Verbündeten, sondern für die ganze Menschheit den endgiltigen Sieg des Friedens erkämpfen.“

Dr. Müller

Protokoll der Besprechung zwischen der deutschen, österr.-ung. und ukrain. Delegation über: Cholmland als nordwestliche Grenze des ukrain. Staates, Sicherung der nationalen und politischen Rechte der Ukrainer in Österreich sowie der Polen in der Ukraine und Abschluß eines Handelsvertrages zwischen den Zentralmächten und der Ukraine.

\section{HHSt.A. P.A. Pr-L 325 Ausfertigung}

Besprechung über politische und allgemeine wirtschaftspolitische Fragen zwischen der deutschen, österreichisch-ungarischen und ukrainischen

Delegation, Donnerstag, den 17. Januar 1918, Nachmittags 5 Uhr.

Die Sitzung wird um 5 Uhr 10 Minuten durch den Staatssekretär von Kühlmann eröffnet.

Staatssekretär von Kühlmann: Wollen wir die heutige Sitzung eröffnen, und will der Herr Erste Delegierte der ukrainischen Delegation uns die gestern in Aussicht gestellten Mitteilungen jetzt machen?

Staatssekretär Holubowytsch: Ich nehme an, daß unsere heutige Sitzung eine öffentliche sein wird.

Staatssekretär von Kühlmann: Von unserer Seite besteht kein Bedürfnis danach. Wir sind ebenso zufrieden, wenn die Sitzungen wie bisher behandelt werden. Oder wird von der Gegenseite Wert darauf gelegt, daß die Sitzung öffentlich sein soll?

Staatssekretär Holubowytsch: Ich meinte das „öffentlich“ nur in dem Sinne, um zu wissen, ob unsere Regierung berechtigt sein könnte, dasjenige aus den heutigen Verhandlungen zu veröffentlichen, was sie für eine Veröffentlichung als geeignet ansehen würde.

Graf Czernin: Ich schließe mich insofern der Ansicht meines deutschen Herrn Kollegen an, daß von unserem Standpunkt aus kein Bedürfnis dafür besteht. Aber wenn die Herren Wert darauf legen, so ist es, glaube ich, schwer, es abzulehnen.

Staatssekretär Holubowytsch: Ehe ich an das Thema der heutigen Sitzung herangehe, möchte ich noch einmal das Resultat zusammenfassen, das auf der gestrigen Sitzung erzielt worden ist. Es war gestern die Rede von zwei Fragen. Die erste von ihnen, die Frage des Gouvernements Cholm, kann, wie aus den gestrigen Unterhaltungen hervorgeht, als grundsätzlich entschieden angesehen werden. Für die Zukunft blieb nur noch übrig, die Hauptpunkte unserer zukünftigen Grenze zu fixieren und diese Lösung der Frage hat uns für den weiteren Gang der Verhandlungen befriedigt. Was die zweite Frage anbetrifft, so haben wir von dem Herrn Vorsitzenden der österreichischungarischen Delegation folgende Erklärung gehört: eine der Hauptaufgaben der österreichischungarischen Regierung würde es sein, die ukrainische Bevölkerung Österreichs in eine Lage zu 
stellen, welche diese Bevölkerung zufrieden stellt, und wir haben das folgendermaßen verstanden, daß die nationalen und politischen Rechte dieser ukrainischen Bevölkerung in dem Sinne gesichert werden sollen, wie dies für die ukrainischen Bevölkerungsteile der österreichischungarischen Monarchie als notwendig erscheint, d. h. daß diesem Teile der Bevölkerung die Möglichkeit eingeräumt werden wird, durch Vermittelung ihrer parlamentarischen Vertretung oder auf irgend einem anderen Wege, um den allgemein gebräuchlichen Ausdruck zu gebrauchen, ihr Recht selbst zu bestimmen. Indem wir die uns zuteil gewordene Antwort in diesem Sinne aufgefaßt haben, halten wir auch sie für den weiteren Gang der Verhandlungen für durchaus befriedigend.

Nach diesen zwei einleitenden Bemerkungen halten wir es für möglich, jetzt an weitere Verhandlungen heranzutreten, die einen wirtschaftlichen Charakter tragen. In dieser Richtung wäre es für uns von großem Interesse, die Absichten des Vierbundes in dieser Richtung zu hören und zu wissen, welche Schritte in dieser Richtung unternommen werden sollen, wenn es zu einem Friedensschluß zwischen uns kommt. Dann könnten wir gewissermaßen auch unseren Standpunkt darstellen, und dieser Standpunkt könnte dann als Grundlage dienen für die weiteren Punkte des Friedensvertrages. - Ich betone noch einmal, daß es für uns sehr wichtig wäre, über diese Fragen Klarheit zu bekommen, damit wir dann, wie ich es schon gestern abend erwähnte, persönlich in Verbindung zu unserer Regierung treten und dann alle Teile dieser Fragen endgültig fixieren.

Graf Czernin: ich muß noch einmal kurz zurückkehren auf die Ausführungen, die Sie gestern gemacht haben und auf die eingehenden

Worte des Herrn Vorsitzenden der Delegation. Ich glaube, daß der Herr Vorsitzende mich vollständig richtig verstanden hat, möchte aber vollständiger Klarstellung halber doch noch einmal das gestrige präzisieren. Ich konstatiere erstens, daß wir uns gestern über das Prinzip der Cholmer Frage tatsächlich geeinigt haben. Ich konstatiere weiter, daß sowohl die Herren der ukrainischen Delegation wie meine Wenigkeit uns darüber geeinigt haben, daß, bevor der neu entstandene ukrainische Staat und die österreichische-ungarische Monarchie in enge freundschaftliche Beziehungen treten, ein vollständige Klarstellung von beiden Seiten der Verhältnisse Platz zu greifen hat. Es soll nichts zwischen den beiden Staaten zurückbleiben, was in Zukunft ein Zankapfel werden könnte. Dies gilt auf der einen Seite so gut wie auf der anderen Seite. Und genau das gleiche Interesse, welches die Herren der ukrainischen Delegation beispielsweise an unseren Ukrainern nehmen, nehmen wir an jenen polnischen Elementen, welche dem zukünftigen ukrainischen Staat eingegliedert sein werden. Man kann diesen Wunsch im allgemeinen richtigerweise in dem Satz zusammenfassen, dass die nationalen und die politischen Rechte der betreffenden Minoritäten eine Sicherung erhalten müssen. Ich betone aber nochmals ausdrücklich, was ich bereits gestern gesagt habe, dass eine solche Erklärung eines führenden Staatsmannes einem fremden Staate gegenüber nur dann möglich ist, wenn die Sicherheit besteht, daß das Verhältnis dieser beiden Staaten ein freundschaftliches und verbündetes wird. Einem fremden oder vielleicht sogar einem in Zukunft wieder feindlichen Staate gegenüber sind Verpflichtungen einzugehen unmöglich. Ich wiederhole daher das, was ich gestern gesagt, habe, daß ich bereit bin à titre der Gegenseitigkeit ein eventuelles Friedensprotokoll zu krönen mit einer Erklärung, welche diese Frage vollkommen klarstellt.

Staatssekretär von Kühlmann: Ich möchte zu dem, was der Herr Vorredner gesagt hat, zu Punkt 1 und 2 nichts weiteres bemerken, da die nötigen Bemerkungen im Namen der österreichischungarischen Delegation bereits abgegeben worden sind.

Was die ökonomischen Fragen betrifft, so kann unsere Delegation nicht im Namen der vier verbündeten Staaten sprechen. Ich glaube aber mit Sicherheit sagen zu können, daß, falls die Durchberatung der wichtigsten Punkte mit unserer Delegation eine Übereinstimmung ergibt, sich auch bei der Beratung mit unseren Verbündeten irgendwelche nennenswerten Schwierigkeiten nicht ergeben werden. Ich würde, wenn es dem Herrn Vorsitzenden der ukrainischen Delegation genehm ist, Exzellenz von Körner bitten, in kurzen Worten die Grundzüge unserer ökonomischen Vorschläge der ukrainischen Delegation zu erklären.

Exzellenz von Körner: Meine Herren, unser Standpunkt ist sehr einfach 
und ergibt sich aus den Verhältnissen. Es liegt nach unserer Auffassung im beiderseitigen Interesse, ebensowohl in dem unsrigen wie in dem der Ukraine, daß möglichst bald der friedliche Warenaustausch und überhaupt der normale wirtschaftliche Verkehr zwischen beiden Ländern wieder hergestellt wird. Wie dieser normale Verkehr für die Zukunft gestaltet werden soll, ist nach unserer Auffassung dadurch gegeben, daß der bisherige wirtschaftliche Verkehr vor dem Kriege zwischen uns und Rußland überhaupt namentlich aber dem südlichen Teile von Rußland, der Ukraine, ein durchaus befriedigender war. Es würde daher unsererseits ausgegangen werden können von dem bisherigen Status. Es würde anzustreben sein, auf diesem Boden wieder einen normalen Verkehr herzustellen. Würden aber von der anderen Seite besondere, abweichende Wünsche geäußert, so würden wir bereit sein, diese in Erwägung zu ziehen. Ich möchte mir deshalb die Frage erlauben, ob die Herren ukrainischen Vertreter geneigt sind, auf denselben Boden zu treten wie wir, oder ob sie von einer anderen Grundlage ausgehen, als wir es tun.

Professor Ostapenko: Soweit wir bisher die Möglichkeit gehabt haben, mit denjenigen Grundzügen bekannt zu werden, die für die Volkskommissare aufgestellt worden sind, und aus den Erklärungen der Vertreter der Mittelmächte, die wir heute hier angehört haben, haben wir den Eindruck gewonnen, als wären die Grundlagen noch nicht in genügender Weise geklärt, auf denen unser zukünftiger wirtschaftlicher Verkehr aufgebaut werden sollte. Sowohl aus der Erklärung der Mittelmächte an die Vertreter der Volkskommissare wie aus den Äußerungen des Herrn Vertreters der Mittelmächte, die wir heute gehört haben, geht hervor, daß als Grundlage für unseren zukünftigen wirtschaftlichen Verkehr dieselben Prinzipien maßgebend sein sollten, wie sie vor dem Kriege in Geltung waren in dem Verkehr mit dem früheren russischen Kaiserreiche. Es ist selbstverständlich, daß darin eine ganze Reihe von Punkten enthalten sind, die auch in Zukunft und zwar auch für eine fernere Zukunft als Grundlage für unseren wirtschaftlichen und Handelsverkehr durchaus maßgebend bleiben werden. Aber in dem großen Komplex von Fragen, die diese bezeichneten Gebiete betreffen, ist ein begrenzter Kreis rein wirtschaftlicher Fragen enthalten, welche für die zukünftigen wirtschaftlichen und Handelsbeziehungen einer gründlichen Durchsicht unterzogen und ganz neu aufgebaut werden müssen, als es bisher der Fall war mit dem früheren russischen Reiche.

Ich möchte in erster Linie auf einen Umstand hinweisen, der Ihnen wahrscheinlich in genügender Weise bekannt ist. Das ist erstens, daß die heutige wirtschaftliche Struktur der Ukraine in keiner Weise derjenigen wirtschaftlichen Struktur gleicht, die früher die Ukraine im Rahmen des russischen Reiches hatte. Es ist Ihnen be-

kannt, dass in der Ukraine durch ein Gesetz das Privateigentum am Landbesitz abgeschafft ist. Ferner wird eine staatliche Kontrolle eingeführt für Handel und Industrie; eine große Zahl der wichtigsten Produkte bildet den Gegenstand eines Staatsmonopols.

Vor einigen Tagen ist im Parlament der ukrainischen Republik ein Gesetzentwurf über ein Aussenhandelsmonopol eingebracht worden. Jetzt wird klar, welche Schwierigkeiten vorhanden sein werden bei der Demobilisierung der wirtschaftlichen Kräfte, soweit sie vom Kriege beeinflusst sind, ferner auch alle Schwierigkeiten der Deckung der ungeheueren Ausgaben, welche mit dem Kriege im Zusammenhange stehen. Das sind die hauptsächlichsten Grundzüge von Seiten der Ukrainer.

Wir haben aber auch den Eindruck, dass das wirtschaftliche Leben der Mittelmächte äusserlich auch jetzt wenig den Zuständen gleich komme, die in Geltung waren, als noch die früheren Verträge mit dem russischen Reiche bestanden. Wir wissen, dass auch bei ihnen die wichtigsten Produkte zentralisiert sind und verteilt werden in den sogenannten Zentralstellen und in dieser oder jener Hinsicht einer genauen Kontrolle des Staates unterworfen sind.

Ein weiterer wichtiger Umstand, der für beide Teile massgebend ist, ist das Fehlen der ausgleichenden Faktoren auf den Weltmärkten. Daher erscheint es uns für eine zukünftige möglichst enge Entwicklung der gegenseitigen wirtschaftlichen Beziehungen absolut notwendig zu sein, jetzt zu beginnen mit der genauen Durchsicht aller Grundstäze für den zukünftigen dauernden Handelsvertrag zwischen beiden Parteien und ferner, einen provisorischen Handelsvertrag abzuschliessen bis zum Wiedereintritt normaler Zustände. 
Wenn es dem Herrn Vorsitzenden genehm ist, könnte ich gleich ausführen, wie wir uns diese Grundlagen vorstellen. Sonst ist es vielleicht auch genehm, dass erst sich eine Aussprache anknüpft an die allgemeinen Grundsätze, die ich eben ausgeführt habe.

Staatssekretär von Kühlmann: Ich bin ganz einverstanden, wenn der Herr Redner gleich seine Gedanken vorbringt.

Professor Ostapenko: Das, was ich gleich vorbringen werde, kann natürlich noch nicht als ein endgültiger Vorschlag für eine endgültige Regelung von Seiten der Ukraine angesehen werden, da technische Schwierigkeiten uns in einem regen Meinungsaustausche mit unserer Regierung über diese Fragen hindern. Wir stehen auf dem Standpunkte, dass es nicht möglich ist, diejenigen Teile des deutsch-russischen Handelsvertrages vom Jahre 1904, die die reinen Handels- und wirtschaftlichen Beziehungen betreffen, zur Grundlage unserer jetzigen Beziehungen zu machen, da dieser Vertrag überhaupt sehr veraltet ist und nicht mehr den Interessen des zu erwartenden deutschukrainischen Handelsverkehrs entspricht. Ferner

erscheint uns als wichtiger Punkt, dass das Prinzip der Schutzzölle ersetzt wird durch das Prinzip der Kontingentierung, d. h. es muss geregelt werden die Einfuhr einer bestimmten Menge von Waren innerhalb eines festgesetzten Termins ohne jede Zollbeschränkung, wie dies der Fall war bei dem früheren deutsch-russischen Handelsvertrag bezüglich der Einfuhr von lebenden Schweinen nach Deutschland. Ferner erschiene es uns sehr wichtig, das Prinzip der Meistbegünstigung zu ersetzen durch das der Gegenseitigkeit unter der Bedingung, dass keine von beiden Parteien einer dritten Partei eine günstigere Position einräumen würde, damit das Prinzip der Gegenseitigkeit nicht seinen Sinn verliert. Als vierter Punkt erschiene es uns von Wichtigkeit, dass unser gesamter Aussenhandel erfolgen sollte entweder von staatlichen Stellen oder durch der staatlichen Kontrolle unterstellte Zentralstellen, und zwar solche Zentralstellen, wie sie entweder bereits während des Krieges bestanden haben, oder aber bei Eröffnung des Wirtschaftsverkehrs noch eingerichtet werden sollen. Diese grundlegenden Punkte könnten vielleicht konditionell angenommen werden als die Grundsätze für einen zukünftigen dauernden Handelsvertrag. Auf derselben Grundlage könnten wir dann vielleicht Verhandlungen über die Art des sofortigen Beginns des gegenseitigen Warenaustausches, und zwar für den Zeitraum vom Tage der Unterzeichnung des Friedensvertrags bis zum 1. Januar 1920. Das sind in kurzen und grossen Umrissen diejenigen Prinzipien, auf denen wir es für möglich halten würden, einerseits den späteren dauernden Warenaustausch zu begründen, andererseits die vorübergehenden Grundsätze bis zum 1. Januar 1920. Ich betone noch einmal, dass dieses nicht unsere endgültigen Vorschläge darstellen, und zwar weil ich schon einmal angeführt habe, dass gerade in der letzten Woche unser Verkehr mit unserer Regierung in Kiew ausserordentlich erschwert war und wir nicht genau wissen können, ob nicht in der Zwischenzeit die Ansichten unserer Regierung sich in dieser Hinsicht geändert haben.

Herr Holubowytsch: Zu diesen Punkten möchte ich noch bemerken, und nochmals betonen, und zwar zu den Schlussausführungen meines Vorredners. Diese hier vorgetragenen Prinzipien stellen die provisorischen Prinzipien dar, von denen wir es für nötig hielten, sie mit denselben bekanntzumachen, um auch von der Gegenseite die entsprechenden Informationen und Vorschläge anzuhören, für die dann die Möglichkeit vorläge, sich eingehend zu beraten. Von unserer Seite dazu irgend welche entsprechende Abänderungen hinzuzufügen und vielleicht noch einige Fragen anzuschneiden und andere Punkte in den Vordergrund zu stellen, nach denen diese hier vorgetragenen Punkte auf Grund eines mündlichen Vortrages unserer Regierung bekannt geworden sind. Ich betone, dass in den vorgetragenen Prinzi-

pien die einen oder anderen Abänderungen wohl annehmbar sind, für die wir dann Hinweise von unserer Regierung bekommen können. Daher erblicken wir in dem heutigen Meinungsaustausche in erster Linie einen Austausch von informativen Charakter.

Professor Ostapenko: Gestattet mir der Herr Vorsitzende an erster Stelle meinen Gedanken noch eine nähere Ausführung zu geben. Das Prinzip der Kontingentierung soll sich hauptsächlich erstrecken auf diejenigen Produkte, die als Produkte des Massenverbrauches angesehen werden, während andre Produkte von beiden Seiten zollfrei zur Einführung gelangen sollten. 
Ministerialdirektor Exzellenz von Koerner: Ich begrüsse zunächst, aus den Worten des Herrn Vorredners entnommen zu haben, dass sie bereit sind, in eingehende Beratungen mit uns über die Grundsätze sowohl eines provisorischen wie eines definitiven Handelsvertrages und, sagen wir vielleicht weiter, wirtschaftlichen Vertrages einzutreten. Zunächst bin ich der Meinung, dass zwischen dem provisorischen Abkommen und dem definitiven doch ein erheblicher Unterschied besteht und bestehen muss. Das provisorische Abkommen betrifft Verhältnisse, die vorübergehender Natur sind und durch den Krieg eine ganz besondere Lage geschaffen haben, während der definitive Vertrag die Verhältnisse nach der Rückkehr zu normalen Zeiten in Betracht ziehen muss. Für beide Verträge, namentlich aber für den definitiven muss meines Erachtens der Ausgangspunkt sein, der tasächlich bestehende Zustand auf beiden Seiten. Wie wir anerkennen, dass die Ukraine ihre wirtschaftlichen Verhältnisse ordnen kann, wie sie es für richtig hält, so müssen auch wir erwarten, dass von der anderen Seite die Verhältnisse, wie sie bei uns sind, als bestehend anerkannt werden und als Grundlage für die Verhandlungen dienen können.

Was zunächst den provisorischen Vertrag anlangt, so sind, wie einer der Herren Vorredner schon erwähnt hat, bei uns die Verhältnisse in gewisser Beziehung ähnlich, wie sie in der Ukraina sind. Ich meine damit, dass auch bei uns eine gewisse staatliche Kontrolle und eine gewisse Zentralisierung des wirtschaftlichen Lebens eingetreten ist, wie sie anscheinend in der Ukraine auch beabsichtigt wird. Also mir scheint vorbehaltlich der Prüfung im einzelnen, dass es nicht allzu schwierig sein wird, für den provisorischen Vertrag eine Grundlage zu finden. Ich glaube aber, wir werden auch für den definitiven Vertrag die Grundlage finden, wenn eben von beiden Seiten anerkannt wird, dass die auf jeder Seite bestehenden Verhältnisse den Ausgangspunkt der Verhandlungen bilden müssen. Die einzelnen Vorschläge, die der Herr Vorredner gemacht hat, bedürfen ja selbstverständlich einer sehr eingehenden und genauen Prüfung und es wird

nicht möglich sein, im Rahmen der heutigen Verhandlung diese Punkte zur endgültigen Erledigung zu bringen.

Ich kann vielleicht zu den einzelnen Punkten noch einige Ausführungen machen. Der ukrainische Herr Vertreter hat als ersten Punkt angeführt, wenn ich ihn richtig verstanden habe, dass diejenigen alten Verträge, die über rein wirtschaftliche Dinge sprechen, nicht als Grundlage des neuen Vertrages angesehen werden könnten; andererseits hat er anerkannt, daß gewisse Teile und ich habe den Eindruck gewonnen, der grössere Teil der Bestimmungen des alten Vertrages auch fernerhin noch sich eignen würde in den künftigen Vertrag aufgenommen zu werden. Wir sind bereit in eine Prüfung der Punkte einzutreten, welche aufrechterhalten werden können und welche nicht aufrechtzuerhalten wären.

Der zweite Punkt war, dass der Herr Vertreter der Ukraine erklärte, das Prinzip der Schutzzölle müsste aufgegeben werden und an dessen Stelle die Kontingentierung gesetzt werden. Aus einer späteren Erklärung des Herrn Vertreters geht aber hervor, dass dieses Prinzip auch nicht ausnahmslos festgehalten werden soll, sondern mit einer gewissen Auswahl für grössere, sagen wir einmal Stapelartikel. Ich entnehme daraus die Hoffnung, dass im Laufe der Verhandlungen auch über diesen Punkt eine Einigung möglich ist. Dabei muss ich allerdings bemerken: Hier tritt der Unterschied zwischen dem provisorischen Vertrage und dem definitiven ganz besonders hervor. Für den provisorischen liegt da die Sache wesentlich günstiger. Es ist Ihnen bekannt, dass wir seit Beginn des Krieges eine ganze Anzahl von Zöllen aufgehoben haben auf Artikel, die gerade für die Einfuhr aus der Ukraine wichtig sind. Wir werden voraussichtlich diese Zollfreiheit auch noch für einige Zeit nach dem Kriege aufrechterhalten müssen und ich halte es nicht für ausgeschlossen, dass wir auch im eigenen Interesse dem Gedanken der Kontingentierung näher treten müssen, wenigstens für einige große Artikel. Ich will sie nicht näher bezeichnen, Sie wissen sie gerade so gut wie ich. Dagegen wird von einer allgemeinen Aufhebung der Schutzzölle von uns wohl kaum die Rede sein können. Es liegen in dieser Beziehung die Verhältnisse bei uns und in der Ukraine doch sehr verschieden. Für die Ukraine handelt es sich um einige grosse Artikel, für uns handelt es sich um eine unendliche Menge einzelner, namentlich Industrieprodukte. Also ich glaube hier sind die Verhältnisse auf beiden Seiten verschieden. Es wird Sache der späteren Erwägungen sein, festzustellen, inwieweit wir Ihrem Standpunkt Rechnung tragen können. 
Als dritten Punkt hat der Vertreter der Ukraina erwähnt, dass das Prinzip der Meistbegünstigung ersetzt werden müsse durch das Prinzip der Reziprozität jedoch mit der Beschränkung, dass man sich

dabei zusagt, keinem dritten Staate grössere Vergünstigungen zu gewähren als einem anderen. Mir kommt vor, dass das eine neue und interessante Verbindung der Meistbegünstigung und des Reziprozitätsprinzips sein würde. Ob sie praktisch möglich ist, wird sich auch erst bei näherer Betrachtung feststellen lassen. Das Prinzip der allgemeinen Meistbegünstigung hat ja immer, aber namentlich in neuerer Zeit viele Anfechtungen gefunden. Das Prinzip der Reziprozität hat ja so beim ersten Anblick manches für sich, aber die praktische Durchführung ist ausserordentlich schwierig. Da aber von ukrainischer Seite noch die allgemeine Meistbegünstigung wieder angeschlossen ist an das Reziprozitätsprinzip, so glaube ich, werden wir uns auch über diese Prinzipienfrage schliesslich einig werden. Das war Punkt 3.

Nun kommt der Punkt 4. Der geht dahin, dass der gesamte Aussenhandel durch staatliche Stellen oder durch staatlich kontrollierte Stellen geführt werden könnte. Für den Uebergangsverkehr, für den provisorischen Vertrag würde eine derartige Zentralisierung und Kontrolle des Handels in gewissem Umfange voraussichtlich auch bei uns möglich sein. Für den definitiven Vertrag wird sich allerdings bei einem Lande mit so entwickelter Industrie und so entwickeltem Verkehr wie Deutschland, so ausgebildeten Handel, wie er in Deutschland besteht, würden sich wahrscheinlich sehr grosse Schwierigkeiten ergeben für eine allgemeine staatliche Kontrolle. Ich kann mich also dahin resumieren, dass die Vorschläge des Herrn ukrainischen Vertreters von uns bereitwilligst einer eingehenden Prüfung unterzogen werden, und ich darf daran die Hoffnung knüpfen, dass bei weiteren Verhandlungen über die einzelnen Punkte eine Uebereinstimmung sich wird herstellen lassen. Ich möchte daher empfehlen, dass wir eine weitere Beratung in Aussicht nehmen und dann die Vorschläge im Einzelnen durchgehen. Selbstverständlich will ich dadurch einer weiteren Aeusserung heute schon zu diesen Fragen nicht vorgreifen.

Exzellenz Gratz: Ich möchte nur einige Fragen stellen, um die Ideen, welche die Herren dargelegt haben, eingehend kennen zu lernen. Selbstverständlich hat ein jeder Staat selbst die Formen zu bestimmen, unter welchen er seine Handelsbeziehungen einrichtet. Wir denken also nicht daran, im Friedensvertrage irgend eine bestimmte Form der Handelsbeziehungen der ukrainischen Republik auferlegen zu wollen. Unsere Handelsbeziehungen mit der ukrainischen Republik werden sich nach den inneren Gesetzen derselben zu regeln haben, so wie in diesem Falle die Beziehungen der ukrainischen Republik auf unseren Gebieten wieder von unseren Gesetzen abhängig wären. Ich möchte nun die Frage aufwerfen, wie nun in dem Friedensvertrage, um den es sich jetzt handelt, vorgegangen werden soll. Die Herren wollen gewisse Bestimmungen des alten Handels-

vertrages nicht erneuern. Ich nehme an, dass es sich in erster Reihe um die zolltarifarischen Bestimmungen handelt. Ein Handelsvertrag im alten Sinne hat nur den Zweck, die Bedingungen festzustellen, unter welchen jedermann aus einem Lande in das andere ausführen oder von dort einführen kann. Habe ich nun die Herren richtig verstanden, wenn ich annehme, dass sie einen solchen Vertrag aus folgenden Gründen für nötig halten? Bei der Ausfuhr und Einfuhr von Massengütern kommt in der Ukraine nur ein Staatsmonopol in Betracht, wo Einfuhr und Ausfuhr von Fall zu Fall auf Grund von Kontingentverträgen stattfinden wird. Andere Nichtmassengüter sollen ohne jede Bedingung eingeführt werden können. Es ist also die Aufstellung von Bedingungen für den Handelsverkehr im ersten Fall unnötig, weil sie von Fall zu Fall festgestellt werden, und in Fällen, in welchen nicht ein Staatsmonopol auf Grund eines Kontingentvertrages etwas verkauft wird, die Einfuhr überhaupt unmöglich ist, während in den andern Nichtmassengütern eine Bedingung für die Einfuhr überhaupt nicht vorliegt. Es wären dann für uns die Gesetze massgebend, die in der Ukraine bestehen, und für die ukrainischen Waren bei uns jene Gesetze, die bei uns für jene Staaten bestehen, mit welchen wir keine Verträge haben. Das System ist so neu, dass ich für einige nähere Aufklärung vom Standpunkt der späteren Besprechung dankbar wäre. Wenn meine Auffassung zutrifft, so würde aus den Ausführungen der Herren folgen, dass in den Friedensvertrag nur Folgendes aufzunehmen wäre: dass für den Verkehr zwischen den beiden Ländern die 
eigenen Gesetze maßgebend sind. Es ist das nicht ein Vorschlag, sondern eine Frage, die ich richten will.

Was nun jene Waren betrifft, die im allgemeinen zollfrei erklärt werden sollen, so ist die Bewilligung einer solchen Zollfreiheit für uns mit grossen Schwierigkeiten verbunden, ja sie ist unmöglich, schon weil wir Meistbegünstigungsverträge haben, auf Grund deren wir dann die Zollfreiheit auch auf andere Staaten ausdehnen müßten. Wie würden wir uns bezüglich dieser Waren stellen, wenn wir die Zollfreiheit nicht von vornherein prinzipiell zugestehen könnten?

Was nun die Kontingentgeschäfte betrifft, so wurden diese an verschiedene Bedingungen verknüpft, welche die Herren erwähnt haben. Solche Bedingungen sind, dass die betreffenden Waren zollfrei eingeführt werden und dass sie durch von den Regierungen begründete Zentralen eingeführt werden usw. Ich glaube nicht, dass es ein Hindernis gibt, solche Kontingentgeschäfte abzuschließen. Es werden in solchen Fällen eben dann von beiden Seiten Bedingungen festgestellt werden, und welche Bedingung angenommen wird, wird dann davon abhängen, ob der Importeur oder der Exporteur das grössere Interesse am Geschäft hat. Prinzipielle Bedenken gegen solche Kontingentgeschäfte bestehen auf unserer Seite nicht. Es könne

auf diesen Grundlagen Handelsgeschäfte jedenfalls auch gleichzeitig mit dem Friedensvertrage abgeschlossen werden. Ich kann mir aber kein rechtes Bild davon machen, wie diese Art von Handelsgeschäften prinzipiell und vertraglich geregelt werden soll. Bei jenen Kontingentgeschäften, auf welche die Herren angespielt haben, sind die Bedingungen immer von Fall zu Fall vereinbart worden. Ich glaube, das wird auch in Zukunft der Fall sein müssen. Wenn die Herren aber eine prinzipielle Regelung dieser Fragen für möglich halten, so möchte ich auch darüber um einige nähere Auskünfte bitten, denn ich kann mir die Form einer solchen Regelung schwer vorstellen.

Staatssekretär von Kühlmann: Ich möchte kurz das Wort ergreifen, um darauf hinzuweisen, daß die Zeit sehr vorgeschritten ist, und dass ich glaube, die Diskussion bewegt sich schon so sehr in technischen Spezialitäten, dass sie den Rahmen dieser allgemein politischen Sitzung überschreitet. Ich möchte daher die Anregung geben, ob es nicht zweckmäßig wäre, dass diejenigen Herren, welche mit der technischen Ausarbeitung dieser Fragen befasst sind, sich in einer Spezialsitzung zusammenfinden, um dort die Diskussion fortzusetzen.

Staatssekretär Holubowytsch: Von unserer Seite liegt dagegen nicht das geringste Hindernis vor.

Staatssekretär von Kühlmann: Dann würde ich vorschlagen, die heutige Sitzung, von der ich das Gefühl habe, dass sie ausserordentlich sachlich war und so viele Fragen erheblich gefördert hat, zu vertagen und es den beteiligten Herren zu überlassen, wenn sie sich zu einer eingehenden Aussprache zusammenfinden wollen.

Ministerialdirektor Exzellenz von Koerner: Ich wollte mir erlauben vorzuschlagen, vielleicht morgen nachmittag um 4 Uhr zusammenzutreffen.

Staatssekretär von Kühlmann: Ich würde vorschlagen, dass, soweit wenigstens wir in Betracht kommen, die Herren Vorsitzenden, die Herren, die vor allem politische Dinge bearbeiten, dabei nicht gegenwärtig zu sein brauchen. Das können die Herren als Spezialdiskussion unter sich erledigen.

Staatssekretär Holubowytsch: Von unserer Seite bestehen nicht die geringsten Hindernisse. Was die Zeit anbetrifft für die nächste Sitzung, so möchten wir nach vorhergehender Abrede darum bitten, dass sie erst auf übermorgen angesetzt wird und zwar möglichst um 5 Uhr.

Staatssekretär von Kühlmann: Unsere nächste allgemeine Sitzung wird nach Vereinbarung angesetzt werden.

Ministerialdirektor Exzellenz von Koerner: Also können wir übermorgen um 5 Uhr hier zusammentreten.

(Schluss der Sitzung um 6 Uhr 46 Minuten) 
Protokoll der Besprechung zwischen der deutschen, österr-ung. und ukrain. Delegation: Einverständnis der Zentralmächte zur Angliederung des Cholmlandes an die Ukr. Republik sowie zur Bildung eines besonderen ukrain. Kronlandes aus Ostgalizien und der Nordbukowina, jedoch unter der Bedingung, daß: 1. der Friedensvertrag bis zum 30. Jänner 1918 abgeschlossen wird und die ukrain. Armee ab 1. Februar 1918 demobilisiert wird; 2. nach Friedensschlu $\beta$ sofortiger Warenaustausch zwischen der Ukraine und den Zentralmächten einsetzt und 3. eine freie nationale und kulturelle Entwicklung für die Polen in der Ukraine gewährleistet wird. - Zur Sprache gelangten auch die Beziehungen der Ukraine zu Rumänien.

\section{HHSt.A. P.A. Pr-L Ausfertigung}

Besprechung über politische Fragen zwischen der deutschen, österreichischungarischen und ukrainischen Delegation.

(Sonnabend, den 19. Jänner 1918, vormittags elf Uhr.) eröffnet.

Die Sitzung wird um elf Uhr 21 Minuten durch den Minister des Aeußern Grafen Czernin

Graf Czernin: Wir haben uns hier zusammengefunden, um zu besprechen, ob wir eine Klarheit darüber erhalten können, auf welcher Basis unsere Verhandlungen zu führen sind oder nicht. Da ich glaube, die Absichten der Herren zu kennen, so bin ich bereit, jene Konzessionen zu erklären, die wir bereit sind, unter ganz bestimmten Gegenbedingungen zu machen. Diese Konzessionen von uns aus wären doppelte:

1.) die Einwilligung dazu, daß der Cholmer Kreis der zukünftigen ukrainischen Republik angehöre;

2.) ein Passus, welcher ungefähr so zu lauten hätte:

„Die beiden vertragschließenden Teile - das wäre also auf der einen Seite die Ukraine, auf der anderen Seite die Zentralmächte - sind beseelt von dem Wunsche, in dauerndem, freundnachbarlichem Verhältnisse zu leben, weshalb Österreich der innerhalb seiner Grenzen wohnenden ukrainischen Bevölkerung, die Ukraina aber den in ihren Grenzen verbleibenden polnischen Minoritäten die volle freie, nationale und kulturelle Entwicklung gewährt.“

Ich füge dem hinzu, daß diese freie, nationale und kulturelle Entwicklung so gedacht ist, daß die Ukrainer Ostgaliziens eine eigene Provinz innerhalb Österreichs bilden würden. Diese Konzessionen, die ich meinerseits als sehr weitgehend erachte, würden aber selbstverständlich nur unter ganz bestimmten Gegenbedingungen in Kraft treten, und dies wären folgende:

„1.) Abschluß des definitiven oder provisorischen Friedensvertrages

zwischen den Zentralmächten und der Ukraina bis längstens 30. d. M.;

2.) nach Abschluß hat sofort ein beide vertragschließenden Teile befriedigender intensiver Warenaustausch zu beginnen; die näheren Details hierüber werden sofort von den Vertretungen der Regierungen ausgearbeitet werden;

3.) sollte vor dem 30. nur ein Präliminarfriede abgeschlossen werden, so wird die sofortige Einleitung von definitiven Friedensverhandlungen festgestellt, welche längstens bis zum 15. Februar abgeschlossen werden müssen. Die Demobilisierung der ukrainischen Armee hat unbedingt mit erstem Februar zu beginnen."

Ich möchte dem noch folgendes hinzufügen:

Wenn wir uns hier auf dieser Basis einigen, dann stelle ich mir den weiteren unmittelbaren Vorgang folgendermaßen vor:

Es wird wahrscheinlich notwendig sein, daß sowohl die Herren der ukrainischen Delegation als auch wir auf einen kurzen Aufenthalt nach Hause fahren, um unserer Regierung zu berichten. Ich stelle mir vor, daß vor dieser Abreise entweder eine Art Präliminarien paraphiert würde oder, was den Zweck auch erreichen würde, daß wir in einer morgen oder übermorgen abzuhaltenden Plenarsitzung eine prinzipielle Einigung konstatieren: die Form wäre zu besprechen. 
Staatssekretär Holubowytsch: Bevor ich auf die eigentliche Frage eingehe, möchte ich zwei noch nicht ganz klargestellte Fragen stellen. Die erste Frage ist die: Was ist unter einem Teile des Gouvernements Cholm zu verstehen? Um welchen Teil handelt es sich hiebei und welches sind seine konkreten Grenzen? Und die zweite Frage wäre: Was bedeutet, genau genommen, der Ausdruck „Ostgalizien“? Denn die ukrainische Bevölkerung erstreckt sich nicht nur auf Ostgalizien, sondern auch auf die Bukowina und auf das ugarskische Rußland, das ist noch ein kleiner Teil jenseits der Karpathen. Zu diesen beiden Fragen würde ich einige Erläuterungen erbitten.

Graf Czernin: Ich kann ganz kurz darauf antworten. Was die Cholmer Frage anbelangt, so ist es ein Mißverständnis, daß ich gesagt hätte, ein Teil des Cholmer Kreises; ich habe jedenfalls sagen wollen: „der Cholmer Kreis“. Das wäre - die Herren haben wohl die Karte — hier der gelbe Teil. Im wesentlichen schwebt uns das vor. Wenn nicht von irgend einer Seite noch Einwendungen kommen, so bin ich bereit, die Grenze auf Grund dieser Karte genau zu fixieren.

Staatssekretär Holubowytsch: Wir bitten darum. Sollen wir darunter das verstehen, was hier auf dieser Karte in gelber Farbe eingezeichnet ist oder nur ein Teil davon?

Graf Czernin: Was meinen Sie (zu Exzellenz von Kühlmann gewendet)? Hatten wir uns auf das Ganze geeinigt? Wenn wir uns einigen werden,

glaube ich, können wir das zugeben; wohlgemerkt, das gilt aber nur, wenn wir uns einigen werden.

General Hoffmann: Was die frühere russische Regierung bereits abgetrennt hatte von dem Generalgouvernement Cholm. Das ist das, was in Frage kommt.

Graf Czernin: Ich meine, damit bei den Herren kein Mißverständnis entsteht, es gilt das alles überhaupt nur, wenn wir einig werden. In diesem Falle gilt das Gelbe.

Staatssekretär Holubowytsch: Durch einen mißverstandenen Ausdruck ist das Mißverständnis entstanden. Ferner handelt es sich noch um den Teil, der nördlich Brest-Litowsk liegt, der hier in dieser Karte nicht eingezeichnet ist.

General Hoffmann: Den habe ich bereits gestern den Herren gezeigt. Hier ist Janow, da würde die Linie dann hier herübergehen (an der Karte demonstrierend). Ich hatte ja nur bestimmt, dies ist rein polnisches Gebiet. Ich hatte nur gesagt: Richtung Pruzana. Da hatte ich kein Bedenken und dann die Grenze in der Weise herüberlaufen zu lassen. Ob das hier herumgehen würde, das muß im einzelnen untersucht werden. Von Seite Euer Exzellenz (zu Exzellenz Kühlmann gewendet) ist dagegen kein Bedenken. Im einzelnen müßte das natürlich festgelegt werden; das kann jetzt nur ganz oberflächlich gesagt werden.

Staatssekretär Holubowytsch: Wir sind auch der Ansicht, daß die Grenze etwa so zu verlaufen hat.

Graf Czernin: Ist der Punkt erledigt?

Staatssekretär Holubowytsch: Ja, jetzt kommt die zweite Frage.

Graf Czernin: Die zweite Frage: Was die ungarische Ukraina anbelangt, ist eine Einbeziehung in dieses Kompromiß vollständig ausgeschlossen, und zwar deshalb, weil durch die ganzen Siedelungsverhältnisse die Sache gar nicht durchführbar ist. Bei dem, was Österreich anlangt, so kann ich jetzt auswendig die Grenzen Ostgaliziens nicht genau angeben. Es sind das die Grenzen, wo eben die erdrückende Majorität der ukrainischen Bevölkerung aufhört zu leben. Natürlich wäre ich aber bereit, die Grenzen, wenn ich sie selber weiß, genau zu fixieren, und es würde sich aus technischen und sachlichen Gründen von selbst ergeben, daß der nördliche Teil der Bukowina, welcher ebenfalls von Ukrainern bewohnt wird, dann eben damit zusammengeschlossen wird. Das ist die Antwort.

Staatssekretär Holubowytsch: Damit wäre die Frage aufgeklärt. Was diejenigen Fragen anbetrifft, die der Herr Minister uns heute zur Entscheidung vorgelegt hat, so sind sie für uns von so weittragender Bedeutung, daß wir sofort auf sie eine Antwort zu erteilen nicht im Stande sind. Wir werden aber sofort nach der jetzigen Sitzung in eine Beratung dieser Fragen eintreten und bei der nächsten $\mathrm{Zu}-$

sammenkunft imstande sein, in diesem oder jenem Sinne zu diesen Fragen Stellung zu nehmen. 
Graf Czernin: Ich möchte nur bemerken, daß ich sehr gern morgen nach Wien fahren möchte, und daher anfragen, ob diese nächste Sitzung noch heute gegen Abend stattfinden kann.

Staatssekretär Holubowytsch: Wir nehmen an, daß das möglich sein wird.

Graf Czernin: Um wieviel Uhr?

Staatssekretär Holubowytsch: Vielleicht um $5 \mathrm{Uhr}$, wie das bisher üblich war, da unsere Gegenwart bei der wirtschaftlichen Besprechung nicht notwendig ist.

Graf Czernin: Das ist mir recht.

Staatssekretär von Kühlmann: Ich möchte dann die ukrainische Delegation fragen, ob Sie über eine Frage, die ich Ihnen schon vor längerer Zeit vorgelegt habe, nämlich über das Verhältnis zu Rumänien, und zwar das politische Verhältnis zu Rumänien, irgendwelche Mitteilungen oder Aufklärungen bekommen haben?

Herr Ssewrjuk: Ganz bestimmt und klar können wir im Augenblick auf diese Frage nicht antworten. Wir haben nur die Nachricht erhalten, daß unsere Regierung eine Abordnung nach Rumänien entsandt hat, um eine Einigung in dem von uns angegebenen Sinne herbeizuführen, und wir nehmen an, daß wir nach unserer Rückkehr aus Kiew erschöpfende Antwort werden erteilen können auf alle uns vom Herrn Staatssekretär gestellten Fragen.

Staatssekretär von Kühlmann: Zeitungsnachrichten zufolge soll der König von Rumänien von Revolutionären - es ist aber nicht ganz klar, ob von Bolschewiki - verhaftet und abtransportiert worden sein. Haben Sie etwas darüber gehört?

General Hoffmann: Es liegt ein offener Funkspruch vor; danach soll die Petersburger Regierung jetzt befohlen haben, den König von Rumänien zu verhaften.

Staatssekretär Holubowytsch: Wir haben zwar noch nichts positives darüber gehört, aber nach indirekten Nachrichten, über die wir verfügen, zweifeln wir daran, daß dies der Fall ist. — Jedenfalls möchten wir den Wunsch aussprechen, vom Herrn Staatssekretär schärfer umrissene konkretere Fragen bezüglich Rumänien zu bekommen.

Staatssekretär von Kühlmann: Die kann ich Ihnen sofort geben. Besteht irgend ein Bundesverhältnis zwischen der Ukraine und Rumänien? Wie ist die Ukraine bei der rumänischen Regierung und wie ist die rumänische Regierung bei der Ukraine diplomatisch vertreten? Besteht zwischen der Ukraine und Rumänien irgendwelche Abmachung wirtschaftlicher oder militärischer Natur? Hat Rumänien und durch welches Organ seine Streitkräfte dem ukrainischen Oberbefehlshaber unterstellt, oder behält die rumänische Armee ihr eigenes unabhängiges Oberkommando, und wie denkt sich die ukrainische Regierung

das Verhältnis, wenn zwischen uns und der Ukraine Frieden geschlossen werden sollte und Rumänien sich diesem Frieden nicht sofort anschließt? Ist dann die Ukraine entschlossen, Rumänien gegenüber die Pflichten der Neutralität in vollem Umfange uns gegenüber anzuerkennen, oder besteht nach Ansicht der ukrainischen Regierung ein Spezialverhältnis zwischen ihr und Rumänien, was ihr die Einhaltung der völkerrechtlichen Neutralität uns gegenüber unmöglich machen würde? Diese Fragen sind für uns von großer Bedeutung, da sie ja mit für uns die Aufklärung bringen werden, ob der Friedensschluß mit der Ukraine auf der ganzen ukrainischen Front für uns tatsächlich die Waffenruhe herbeiführen wird, oder ob wir unabhängig davon Maßregeln gegen Rumänien, die rumänische Armee ins Auge fassen müssen.

Graf Czernin: Ich möchte noch eine Frage hinzufügen: Was ist mit der sogenannten moldawischen Republik - das ist also Besarabien - und in welchem Verhältnis steht die zur Ukraine und zu Rumänien?

Staatssekretär Holubowytsch: Soweit diese Fragen für uns nicht ganz klar gestellt sind, können wir in diesem Augenblick keine Antwort darauf erteilen.

Staatssekretär von Kühlmann: Ich wollte sie nur stellen, damit der Wunsch der ukrainischen Delegation nach größter Präzisierung der Punkte, die für uns wichtig sind, erfüllt wird.

Staatssekretär Holubowytsch: Ich bin sehr dankbar für die Art der Fragestellung seitens des Herrn Vorsitzenden der deutschen Delegation, da sie für uns die Klarheit bedeutend erleichtern wird. Sowie wir genügende Auskunft erhalten haben, werden wir eine Antwort auf diese Fragen erteilen, soweit durch diese Antwort nicht unsere Souveränitätsrechte verletzt werden. Wir hoffen 
jedenfalls die Mehrzahl und möglichst alle Sie hier interessierenden Fragen beantworten zu können.

Graf Czernin: Ich möchte wissen, ob diese Fragen voraussichtlich heute nachmittag beantwortet werden können, weil sie im Kontakt stehen und mit zu unserer Information in der Sache dienen.

Staatssekretär Holubowytsch: Auf die Fragen des Herrn Vorsitzenden der österreichischen Delegation werden wir in der heutigen Nachmittagssitzung eine wenn auch vielleicht nicht vollständig erschöpfende, so doch genügend klare Antwort geben können.

Graf Czernin: Nein, das habe ich nicht gefragt. Ich habe gefragt, ob wir auf die Fragen Seiner Exzellenz des Herrn Staatssekretärs eine Antwort bekommen würden. Das andere haben wir ja schon gewußt.

Staatssekretär Holubowytsch: Eine Antwort auf die Fragen des Herrn Staatssekretärs noch heute zu erteilen, würde für uns sehr schwierig, eigentlich so gut wie unmöglich sein.

Staatssekretär von Kühlmann: Das habe ich auch gar nicht erwartet.

Graf Czernin: Ich möchte noch eins erwähnend hinzufügen, was ich neulich gesagt habe, was die Form der eventuellen Abmachung betrifft. Die diesbezüglichen eventuellen Abmachungen zwischen uns und der Ukraine müssen zwei Bedingungen entsprechen. Sie müssen erstens absolut klar sein und absolute Garantien geben, und sie können zweitens zum Teile nicht in einem Friedensvertrag niedergelegt werden, sondern in einem Geheimvertrage, und sie sind drittens, wie ich dies neulich schon gesagt habe, aufgebaut auf dem Prinzip der Reziprozität bezüglich der polnischen Minoritäten in der Ukraine.

Staatssekretär Holubowytsch: Ich kann nur den zweiten Punkt hier beantworten. Für uns sind Geheimverträge in dem Sinne, wie sie allgemein verstanden werden, unannehmbar. In diesem Falle ist aber vielleicht der Vorschlag für uns annehmbar in einer besonderen Form eines Vertrages, der nicht veröffentlicht wird.

Graf Czernin: Das ist das, was ich meine.

Staatssekretär von Kühlmann: Ich möchte hinzufügen, damit die Herren auch über unsere Haltung genügende Klarheit haben, daß ich der Anschauung bin, daß das, was heute der Herr Vorsitzende der österreichisch-ungarischen Delegation der ukrainischen Delegation geboten hat, das absolute Maximum dessen ist, zu dem die verbündeten Völker sich entschließen werden, und fernerhin, daß das Zustandekommen einer wenn auch rudimentären, aber ausreichenden Verabredung über die Handelspunkte für uns eine conditio sine qua non für das Zustandekommen des Vertrages ist. $\mathrm{Da}$ ich voraussichtlich auch in den allernächsten Tagen zu Beratungen mit meiner Regierung nach Hause gehen muß, so würde ich den Herren der ukrainischen Delegation empfehlen, die Arbeiten und zwar in einer faßbaren, greifbaren Form fertigzustellen, um unseren Regierungen bereits etwas Formuliertes vorlegen zu können.

Staatssekretär Holubowytsch: Wir nehmen diese Bemerkungen zur Kenntnis und werden eine Antwort darauf auf der nächsten Sitzung erteilen.

Herr Lewytsjkyj: Dürfen wir darum bitten, daß diese Karte uns hier zur nächsten Sitzung überlassen wird?

General Hoffmann: Bitte sehr.

Staatssekretär Holubowytsch: Ich habe noch eine Bitte. Ich möchte bitten, daß uns je ein Exemplar sämtlicher stenographischer Berichte überlassen wird, und zwar möglichst unterschrieben und beglaubigt, da wir nicht im Besitz von Originalen sind. Wenn es auf Schwierigkeiten stoßen würde, diese zu beglaubigen, so würde es uns genügen, wenn irgend eine amtliche Unterschrift auf diesen Stenogrammen wäre. Ich möchte nur noch bemerken, daß der Teil der Protokolle, der auf Grund der Verabredungen zwischen uns nicht zu veröffentlichen ist,

selbstverständlich nicht in die Öffentlichkeit gelangen wird. Mögen die Verhandlungen in dieser oder jener Weise enden, so werden jedenfalls alle Verabredungen bezüglich dieser Protokolle aufs genaueste innegehalten werden. 
Graf Czernin: Ich möchte dazu folgendes bemerken. Wenn die Verhandlungen zu keinem Resultate führen, sind ja die Protokolle gegenstandslos; führen sie zu einem Resultat, dann nehme ich als selbstverständlich an, daß wir uns über die Art und Weise der Verwertung erst verständigen.

Staatssekretär Holubowytsch: Das ist schon eine Zukunftsfrage.

Graf Czernin: Ja natürlich, aber das muß man doch wissen.

Staatssekretär von Kühlmann: Haben Sie etwas dagegen, daß die Protokolle den Herren gegeben werden?

Graf Czernin: Nein.

Staatssekretär von Kühlmann: Sie werden meiner Ansicht nach zweckmäßig für die Richtigkeit nur von dem betreffenden Protokollführer unterschrieben.

Staatssekretär Holubowytsch: Das genügt uns. Es ist mir nur wichtig, diese Protokolle zu haben für die Berichte, die ich meiner Regierung zuhause erstatten muß, umsomehr, als wir bereits im Besitz der Protokolle sind, aber nur beglaubigte Exemplare haben möchten.

Graf Czernin: Die Sitzung ist geschlossen.

(Schluß der Sitzung 12,03 Uhr.)

Der deutsche Text des Brester Friedensvertrages mit der Ukr. Volksrepublik.

HHSt.A. P.A. 523 G-L XLVII/12g Abschrift

Friedensvertrag

zwischen Deutschland, Österreich-Ungarn, Bulgarien und der Türkei einerseits und der Ukrainischen Volksrepublik andererseits.

Da das ukrainische Volk sich im Laufe des gegenwärtigen Weltkrieges als unabhängig erklärt und den Wunsch ausgedrückt hat, zwischen der Ukrainischen Volksrepublik und den mit Rußland im Kriege befindlichen Mächten den Friedenszustand herzustellen, haben die Regierungen Deutschlands, Österreich-Ungarns, Bulgariens und der Türkei beschlossen, mit der Regierung der Ukrainischen Volksrepublik einen Friedensvertrag zu vereinbaren; sie wollen damit den ersten Schritt tun zu einem dauerhaften und für alle Teile ehrenvollen Weltfrieden, der nicht nur den Schrecknissen des Krieges ein Ende setzen, sondern auch zur Wiederherstellung der freundschaftlichen Beziehungen zwischen den Völkern auf politischem, rechtlichem, wirtschaftlichem und geistigem

Gebiete führen soll. Zu diesem Zwecke sind die Bevollmächtigten der vorbezeichneten Regierungen, nämlich:

für die Kaiserlich Deutsche Regierung der Staatssekretär des Auswärtigen Amtes, Kaiserlich Wirklicher Geheimer Rat:

Herr Richard von Kühlmann,

für die k. und k. gemeinsame österreichisch-ungarische Regierung der Minister des Kaiserlich und Königlichen Hauses und des Äussern, Seiner k. und k. Apostolischen Majestät Geheimer Rat,

Ottokar Graf Czernin von und zu Chudenitz,

für die Königlich Bulgarische Regierung der Ministerpräsident,

Herr Dr. Wassiel Radoslavoff,

der Gesandte Herr Andrea Toseheff,

der Gesandte Herr Ivan Stoyanovitch,

der Militärbevollmächtigte Herr Oberst Peter Gantschew,

Herr Dr. Theodor Anastassoff,

für die Kaiserlich Osmanische Regierung:

Seine Hoheit der Großvezier Talaat Pascha,

der Minister des Äußern Ahmed Nessimi Bey,

Seine Hoheit Ibrahim Hakki Pascha,

der General der Kavallerie Ahmed Izzet Pascha, 
für die Regierung der Ukrainischen Volksrepublik:

die Mitglieder der Ukrainischen Zentralrada:

Herr Alexander Ssewrjuk,

Herr Mikola Lubynsjkyj und

Herr Mikola Lewytsjkyj,

zur Einleitung von Friedensverhandlungen in Brest-Litowsk zusammengetreten und haben sich, nach Vorlage ihrer in guter und gehöriger Form befundenen Vollmachten, über folgende Bestimmungen geeinigt:

\section{Artikel I.}

Deutschland, Österreich-Ungarn, Bulgarien und die Türkei einerseits und die Ukrainische Volksrepublik andererseits erklären, daß der Kriegszustand zwischen ihnen beendet ist. Die vertragschließenden Parteien sind entschlossen, miteinander fortan in Frieden und Freundschaft zu leben.

Artikel II.

1. Zwischen Österreich-Ungarn einerseits und der Ukrainischen Volksrepublik andererseits werden, insoweit diese beiden Mächte aneinander grenzen werden, jene Grenzen bestehen, welche vor Ausbruch des gegenwärtigen Krieges zwischen der Österreichisch-Ungarischen Monarchie und Rußland bestanden haben.

2. Weiter nördlich wird die Grenze der Ukrainischen Volksrepublik

von Tarnograd an angefangen im allgemeinen in der Linie Bilgoraj-Szcezebrzszyn - KrasnostawPugaszow-Radin-Meshiretschie - Sarnaki - Melnik - Wysoko-Litowsk - Kamenietz-Litowsk - Pruschany - Wygonowskojesce verlaufen.

Im einzelnen wird diese Grenze nach den ethnographischen Verhältnissen und unter Berücksichtigung der Wünsche der Bevölkerung durch eine gemischte Kommission festgesetzt werden.

3.Für den Fall, daß die Ukrainische Volksrepublik noch mit einer anderen der Mächte des Vierbundes gemeinsame Grenzen haben sollte, werden hierüber besondere Vereinbarungen vorbehalten.

\section{Artikel III.}

Die Räumung der besetzten Gebiete wird unverzüglich nach der Ratifikation des gegenwärtigen Friedensvertrages beginnen.

Die Art der Durchführung der Räumung und die Übergabe der geräumten Gebiete werden durch Bevollmächtigte der interessierten Teile bestimmt werden.

\section{Artikel IV.}

Die diplomatischen und konsularischen Beziehungen zwischen den vertragschließenden Teilen werden sofort nach der Ratifikation des Friedensvertrages aufgenommen werden. Wegen möglichst weitgehender Zulassung der beiderseitigen Konsuln bleiben besondere Vereinbarungen vorbehalten.

\section{Artikel V.}

Die vertragschließenden Teile verzichten gegenseitig auf den Ersatz ihrer Kriegskosten, das heißt der staatlichen Aufwendungen für die Kriegführung sowie auf den Ersatz der Kriegsschäden, das heißt derjenigen Schäden, die ihnen und ihren Angehörigen in den Kriegsgebieten durch militärische Maßnahmen mit Einschluß aller im Feindesland vorgenommenen Requisitionen entstanden sind.

\section{Artikel VI.}

Die beiderseitigen Kriegsgefangenen werden in ihre Heimat entlassen werden, soweit sie nicht mit Zustimmung des Aufenthaltsstaates in seinen Gebieten zu bleiben oder sich in ein anderes Land zu begeben wünschen.

Die Regelung der hiemit zusammenhängenden Fragen erfolgt durch die im Artikel VIII vorgesehenen Einzelverträge. 
Artikel VII.

Über die wirtschaftlichen Beziehungen zwischen den vertragschließenden Teilen wird Folgendes vereinbart:

I.

Die vertragschließenden Teile verpflichten sich gegenseitig, unverzüglich die wirtschaftlichen Beziehungen anzuknüpfen und den Warenaustausch auf Grund folgender Bestimmungen zu organisieren:

Bis zum 31. Juli des laufenden Jahres ist der gegenseitige Austausch der Überschüsse der wichtigsten landwirtschaftlichen und industriellen Produkte zur Deckung der laufenden Bedürfnisse nach Maßgabe der folgenden Bestimmungen durchzuführen:

a) Die Mengen und die Art der Produkte, deren Austausch im vorhergehenden Absatze vorgesehen ist, werden auf jeder Seite durch eine Kommission festgestellt, die aus einer gleichen Anzahl von Mitgliedern beider Seiten besteht und sofort nach Unterzeichnung des Friedensvertrages zusammentritt.

b) Die Preise der Produkte beim erwähnten Warenaustausch- werden auf Grund gegenseitiger Vereinbarung durch eine Kommission festgestellt, die aus der gleichen Zahl von Mitgliedern der beiden Seiten besteht.

c) Die Verrechnung erfolgt in Gold auf folgender Basis: 1000 deutsche Reichsmark in Gold $=462$ Karbowanjec Gold der Ukrainischen Volksrepublik $=462$ Rubel Gold des früheren russischen Kaiserreiches (1 Rubel =1/15 Imperial) oder 1000 österreichische und ungarische Kronen Gold = 393 Karbowanjec 78 Grosch Gold der Ukrainischen Volksrepublik = 393 Rubel 78 Kopeken Gold des früheren russischen Kaiserreiches (1 Rubel = 1/15 Imperial).

d) Der Austausch der Waren, die durch die in Absatz a) vorgesehene Kommission festgestellt werden, erfolgt durch die staatlichen Zentralstellen oder durch vom Staate kontrollierte Zentralstellen.

Der Austausch jener Produkte, welche durch die oben vorgesehenen Kommissionen nicht festgestellt werden, erfolgt im Wege des freien Verkehres unter den Bedingungen des provisorischen Handelsvertrages, der in der folgenden Ziffer II vorgesehen ist.

II.

Soweit nicht in Ziffer I anderes vorgesehen ist, sollen den wirtschaftlichen Beziehungen zwischen den vertragschließenden Teilen provisorisch bis zum Abschlüsse eines endgültigen Handelsvertrages, jedenfalls aber bis zum Ablaufe von mindestens sechs Monaten nach Abschluß des Friedens zwischen Deutschland, Österreich-Ungarn, Bulgarien und der Türkei einerseits und den zur Zeit mit ihnen im Kriege befindlichen europäischen Staaten, den Vereinigten Staaten von Amerika und Japan anderseits folgende Bestimmungen zugrunde gelegt werden:

A.

Für die wirtschaftlichen Beziehungen zwischen dem Deutschen Reiche und der Ukrainischen Volksrepublik diejenigen Vereinbarungen, die in den nachstehenden Bestimmungen des deutschrussischen Handelsund Schiffahrtsvertrages von 1894/1904 niedergelegt sind, nämlich:

Artikel 1 bis 6, 7, einschließlich der Tarife A und B, 8 bis 10,12, 13 bis 19, ferner in den Bestimmungen im Schlußprotokoll, erster Teil, zu Artikel 1, Absatz 1 und 3, zu Artikel 1 und 12, Absatz 1, 2, 4, 5, 6, 8, 9, zu Artikel 3, zu Artikel 5, Absatz 1 und 2, zu Artikel 5, 6, 7, 9 und 10, zu Artikel 6, 7 und 11, zu Artikel 6 bis 9, zu Artikel 6 und 7, zu Artikel 12, Absatz 1, 2, 3, 5, ferner in dem Schlußprotokoll, vierter Teil, die $\S \S 3,6,7,12,12$ b, 13, 14, 15, 16, 17, 18 (mit Vorbehalt der entsprechenden Änderung der Behördenorganisationen), 19, 20, 21, 23.

Dabei besteht Einverständnis über folgende Punkte:

1. Der allgemeine russische Zolltarif vom 13./26. Januar 1903 bleibt aufrechterhalten.

2. Der Artikel 5 erhält folgende Fassung:

„Die vertragschließenden Teile verpflichten sich, den gegenseitigen Verkehr durch keinerlei Einfuhr-, Ausfuhr- oder Durchfuhrverbote zu hemmen und die freie Durchfuhr zu gestatten. 
Ausnahmen sind nur für solche Erzeugnisse zulässig, welche auf dem Gebiete eines der vertragschließenden Teile den Gegenstand eines Staatsmonopols bilden oder bilden werden sowie auch für gewisse Erzeugnisse, für die aus Rücksichten auf die Gesundheit, die Veterinärpolizei und die öffentliche Sicherheit oder aus anderen schwerwiegenden politischen und wirtschaftlichen Gründen außerordentliche Verbotsmaßregeln, insbesondere im Zusammenhange mit der auf den Krieg folgenden Übergangszeit, ergehen könnten."

3. Kein Teil wird die Begünstigungen in Anspruch nehmen, welche der andere Teil irgendeinem anderen Staate auf Grund einer bestehenden oder künftigen Zolleinigung, wie sie zum Beispiele zwischen dem Deutschen Reiche und dem Großherzogtume Luxemburg besteht, oder im kleinen Grenzverkehre bis zu einer Grenzzone von 15 Kilometern Breite gewährt oder gewähren wird.

4. Artikel 10 erhält folgende Fassung:

„Die Waren aller Art, welche durch das Gebiet eines der beiden Teile durchgeführt werden, sollen wechselseitig von jeder Durchgangsabgabe frei sein, sei es, daß sie unmittelbar durchgeführt werden, sei es, daß sie während der Durchfuhr abgeladen, eingelagert und wieder aufgeladen werden“".

5. An Stelle des Artikels 12 a) soll folgende Bestimmung treten:

“a) Hinsichtlich des gegenseitigen Schutzes des Urheberrechts an Werken der Literatur, Kunst und Photographie sollen im Verhältnis

zwischen Deutschland und der Ukrainischen Volksrepublik die Bestimmungen des zwischen dem Deutschen Reiche und Rußland geschlossenen Vertrages vom 28. Februar 1913 gelten.

b) Hinsichtlich des gegenseitigen Schutzes der Warenbezeichnungen sollen die Bestimmungen der Deklaration vom 23./11. Juli 1873 auch in Zukunft maßgebend sein.“

6. Die Bestimmung des Schlußprotokolls zu Artikel 19 erhält folgende Fassung:

„Die vertragschließenden Teile werden einander im Eisenbahntarifwesen, insbesondere durch Erstellung direkter Tarife, tunlichst unterstützen. $\mathrm{Zu}$ diesem Zwecke sind beide vertragschließenden Teile bereit, möglichst bald in Verhandlungen miteinander zu treten.“

7. $\S 5$ des vierten Teiles des Schlußprotokolls erhält folgende Fassung:

„Es besteht beiderseitiges Einverständnis, daß die Zollämter der beiden Länder an allen Tagen des Jahres geöffnet bleiben mit Ausnahme der Sonntage und der gesetzlichen Feiertage.“

B.

Für die wirtschaftlichen Beziehungen zwischen Österreich-Ungarn und der Ukrainischen Volksrepublik diejenigen Vereinbarungen, die in den nachstehenden Bestimmungen des österreichischungarisch-russischen Handels- und Schiffahrtsvertrages vom 15. Februar 1906 niedergelegt sind, nämlich:

Artikel 1, 2, 5, einschließlich der Tarife A und B, Artikel 6, 7, 9 bis 13, Artikel 14, Absatz 2 und 3, Artikel 15 bis 24, ferner in den Bestimmungen im Schlußprotokoll zu Artikel 1 und 12, Absatz 1, 2, 4, 5, und 6, zu Artikel 2, (3 und 5, lies:) zu Artikel 2, 3 und 5, zu Artikel 2 und 5, zu Artikel 2, 4, 5, 7 und 8, zu Artikel 2, 5, 6 und 7, zu Artikel 17 sowie zu Artikel 22, Absatz 1 und 3.

Dabei besteht Einverständnis über folgende Punkte:

1. Der allgemeine russische Zolltarif vom 13./26. Januar 1903 bleibt aufrechterhalten.

2. Artikel 4 erhält folgende Fassung:

„Die vertragschließenden Teile verpflichten sich, den gegenseitigen Verkehr zwischen ihren Gebieten durch keinerlei Einfuhr-, Ausfuhr- oder Durchfuhrverbote zu hindern.

Ausnahmen hievon dürfen nur stattfinden:

a) Bei Tabak, Salz, Schießpulver oder sonstigen Sprengstoffen, sowie bei anderen Artikeln, welche jeweils in den Gebieten eines der vertragschließenden Teile den Gegenstand eines Staatsmonopols bilden;

b) in Beziehung auf Kriegsbedürfnisse unter außerordentlichen Umständen;

c) aus Rücksichten der öffentlichen Sicherheit, aus Gesundheits- und Veterinärpolizeirücksichten; 
d) bei gewissen Erzeugnissen, für die aus anderen schwerwiegenden politischen und wirtschaftlichen Gründen außerordentliche Verbotsmaßregeln, insbesondere im Zusammenhange mit der auf den Krieg folgenden Übergangszeit, sich ergeben könnten.“

3. Kein Teil wird die Begünstigungen in Anspruch nehmen, welche der andere Teil irgendeinem anderen Staate auf Grund einer bestehenden oder künftigen Zolleinigung, wie sie zum Beispiele zwischen Österreich-Ungarn und dem Fürstentume Liechtenstein besteht oder im kleinen Grenzverkehr bis zu einer Grenzzone von 15 Kilometer Breite gewährt oder gewähren wird.

4. Artikel 8 erhält folgende Fassung:

„Die Waren aller Art, welche durch die Gebiete eines der vertragschließenden Teile durchgeführt werden, sollen wechselseitig von jeder Durchfuhrabgabe frei sein, sei es, daß sie unmittelbar durchgeführt werden, sei es, daß sie während der Durchfuhr abgeladen, eingelagert und wieder aufgeladen werden."

5. Die Bestimmung des Schlußprotokolls zu Artikel 21 erhält folgende Fassung:

„Die vertragschließenden Teile werden einander im Eisenbahntarifwesen, insbesondere durch Erstellung direkter Tarife, tunlichst unterstützen. Zu diesem Zwecke sind beide vertragschließenden Teile bereit, möglichst bald in Verhandlungen miteinander zu treten."

\section{C.}

Was die wirtschaftlichen Beziehungen zwischen Bulgarien und der Ukrainischen Volksrepublik betrifft, so sollen sich diese bis zum Abschluß eines definitiven Handelsvertrages nach dem Rechte der meistbegünstigten Nation regeln.

Kein Teil wird die Begünstigungen in Anspruch nehmen, welche der andere Teil irgendeinem anderen Staate auf Grund einer bestehenden oder künftigen Zolleinigung oder im kleinen Grenzverkehr bis zu einer Grenzzone von 15 Kilometern Breite gewährt oder gewähren wird.

D.

Was die wirtschaftlichen Beziehungen zwischen dem Osmanischen Reiche und der Ukrainischen Volksrepublik betrifft, so werden sich beide Teile bis zum Abschlusse des neuen Handelsvertrages gegenseitig dieselbe Behandlung gewähren, welche sie auf die meistbegünstigte Nation anwenden.

Kein Teil wird die Begünstigungen in Anspruch nehmen, welche der andere Teil irgendeinem anderen Staat auf Grund einer bestehenden oder künftigen Zolleinigung oder im kleinen Grenzverkehr gewährt oder gewähren wird.

III.

Die Gültigkeitsdauer der in Ziffer II des gegenwärtigen Vertrages für die wirtschaftlichen Beziehungen zwischen Deutschland, Österreich-Ungarn, Bulgarien und dem Osmanischen Reich einerseits und der Ukrainischen Volksrepublik anderseits vorgesehenen provisorischen Bestimmungen kann im beiderseitigen Einverständnisse der Parteien verlängert werden.

Wenn die im ersten Absatze der Ziffer II vorgesehenen Termine nicht vor dem 30. Juni 1919 eintreten sollten, steht es jedem der beiden vertragschließenden Teile frei, die in der obengenannten Ziffer enthaltenen Bestimmungen vom 30. Juni 1919 an sechsmonatlich zu kündigen.

IV.

A.

Die Ukrainische Volksrepublik wird keinen Anspruch erheben auf die Begünstigungen, welche Deutschland an Österreich-Ungarn oder an ein anderes mit ihm durch ein Zollbündnis verbundenes Land, das an Deutschland unmittelbar oder durch ein anderes mit ihm oder Österreich-Ungarn zollverbündetes Land mittelbar angrenzt, oder welche Deutschland seinen eigenen Kolonien, auswärtigen Besitzungen und Schutzgebieten oder denen der mit ihnen zollverbündeten Länder gewährt.

Deutschland wird keinen Anspruch erheben auf die Begünstigungen, welche die Ukrainische Volksrepublik an ein anderes mit ihr durch ein Zollbündnis verbundenes Land, das an die Ukraine unmittelbar oder durch ein anderes mit ihr zollverbündetes Land mittelbar angrenzt, oder den Ko- 
lonien, auswärtigen Besitzungen und Schutzgebieten eines der mit ihr zollverbündeten Länder gewährt.

B.

Im wirtschaftlichen Verkehre zwischen dem Vertragszollgebiete der beiden Staaten der österreichisch-ungarischen Monarchie einerseits und der Ukrainischen Volksrepublik anderseits wird die Ukrainische Volksrepublik keinen Anspruch erheben auf die Begünstigungen, welche ÖsterreichUngarn an Deutschland oder an ein anderes mit ihm durch ein Zollbündnis verbundenes Land gewährt, das an Österreich-Ungarn unmittelbar oder durch ein anderes mit ihm oder Deutschland zollverbündetes Land mittelbar angrenzt. Kolonien, auswärtige Besitzungen und Schutzgebiete werden in dieser Beziehung dem Mutterlande gleichgestellt.

Österreich-Ungarn wird keinen Anspruch erheben auf die Begünstigungen, welche die Ukrainische Volksrepublik an ein anderes mit ihr durch ein Zollbündnis verbundenes Land, das an die Ukraine unmittelbar

oder durch ein anderes mit ihr zollverbündetes Land mittelbar angrenzt, oder den Kolonien, auswärtigen Besitzungen und Schutzgebieten eines der mit ihr zollverbündeten Länder gewährt.

V.

A.

Soweit in neutralen Staaten Waren lagern, welche aus Deutchland oder der Ukraine stammen, die aber mit der Verpflichtung belegt sind, daß sie weder unmittelbar noch mittelbar nach den Gebieten des anderen vertragschließenden Teiles ausgeführt werden dürfen, sollen derartige Verfügungsbeschränkungen im Verhältnisse zu den vertragschließenden Teilen aufgehoben werden. Die beiden vertragschließenden Teile verpflichten sich daher, den Regierungen der neutralen Staaten von der vorerwähnten Aufhebung dieser Verfügungsbeschränkung unverzüglich Kenntnis zu geben.

B.

Soweit in neutralen Staaten Waren lagern, welche aus Österreich-Ungarn oder der Ukraine stammen, die aber mit der Verpflichtung belegt sind, daß sie weder unmittelbar noch mittelbar nach den Gebieten des anderen vertragschließenden Teiles ausgeführt werden dürfen, sollen derartige Verfügungsbeschränkungen im Verhältnisse zu den vertragschließenden Teilen aufgehoben werden. Die beiden vertragschließenden Teile verpflichten sich daher, den Regierungen der neutralen Staaten von der vorerwähnten Aufhebung dieser Verfügungsbeschränkung unverzüglich Kenntnis zu geben.

\section{Artikel VIII.}

Die Herstellung der öffentlichen und privaten Rechtsbeziehungen, der Austausch der Kriegsgefangenen und der Zivilinternierten, die Amnestiefrage sowie die Frage der Behandlung der in die Gewalt des Gegners geratenen Handelsschiffe werden in Einzelverträgen mit der Ukrainischen Volksrepublik geregelt, welche einen wesentlichen Bestandteil des gegenwärtigen Friedensvertrages bilden und, soweit tunlich, gleichzeitig mit diesem in Kraft treten.

Artikel IX.

Die in diesem Friedensvertrage getroffenen Vereinbarungen bilden ein unteilbares Ganzes.

Artikel X.

Bei der Auslegung dieses Vertrages sind für die Beziehungen zwischen Deutschland und der Ukraine der deutsche und der ukrainische Text, für die Beziehungen zwischen Österreich-Ungarn und der Ukraine der deutsche, der ungarische und der ukrainische Text, für die Beziehun-

gen zwischen Bulgarien und der Ukraine der bulgarische und der ukrainische Text und für die Beziehungen zwischen der Türkei und der Ukraine der türkische und der ukrainische Text maßgebend. 


\section{Schlußbestimmung.}

Der gegenwärtige Friedensvertrag wird ratifiziert werden. Die Ratifikationsurkunden sollen tunlichst bald in Wien ausgetauscht werden. Der Friedensvertrag tritt, soweit darin nichts anderes bestimmt ist, mit seiner Ratifikation in Kraft.

$\mathrm{Zu}$ Urkund dessen haben die Bevollmächtigten diesen Vertrag unterzeichnet und mit ihren Siegeln versehen.

Ausgefertigt in fünffacher Urschrift in Brest-Litowsk am 9. Februar 1918.

Graf Ottokar Czernin m.p.

Minister des k. u. k. Hauses

und des Äußern.

R. v. Kühlmann m. p.
A. Ssewrjuk m.p.

Mikola Lubynsjkyj m.p.

M. Lewytsjkyj m.p.

Als Vertreter der Deutschen Obersten Heeresleitung:

Hoffmann m.p.

Generalmajor und Chef des Generalstabes des Oberbefehlshabers Ost.

Dr. V. Radoslavoff m.p.

A. Tocheff m.p.

Stojanowitsch m.p.

Oberst P. Gantschew m.p.

Dr. Anastassoff m.p.

Talaat m.p.

I. Hakky m.p.

Ahmed Nessimi m.p.

A. Izzet m.p.

Notiz zum Artikel VII des Friedensvertrages vom 9. Februar 1918.

Es besteht Einverständnis darüber, daß das im zweiten Absatze der Ziffer III des oben genannten Artikels enthaltene Kündigungsrecht hinsichtlich der einzelnen (in Ziffer II unter A, B, C, D angeführten) Vereinbarungen jeder der an diesen einzelnen Vereinbarungen beteiligten Parteien selbständig zusteht.

Es soll daher in diesem Absatze statt ,jedem der beiden vertragschließenden Teile“ heißen: ,jedem der fünf vertragschließenden Teile.“

Brest-Litowsk, am 9. Februar 1918.
S. Ssewrjuk m.p.
R. v. Kühlmann m.p.
Czernin m.p.
Talaat m.p.
Dr. V. Radoslavoff m.p.

Protokoll der Sitzung der politischen Kommission der deutschen, österr.- ung. und russ. Delegation: Einwände Trotzkis gegen den Abschluß des Friedensvertrages mit der Ukr. Republik; Entgegnung Czernins und Kühlmanns.

HHSt.A. P.A. Pr-L 325 Auszug. Ausfertigung

Sitzung der politischen Kommission der deutschen, österreichisch-ungarischen und russischen Delegation.

Sonnabend, den 9. Februar 1918, Nachmittags 5 Uhr.

Die Sitzung wird um 5 Uhr 13 Minuten durch den Staatssekretär des Auswärtigen Amtes von Kühlmann eröffnet. 


\section{Herr Trotzki:}

Hier steht vor uns eine neue Schwierigkeit; sie betrifft den uns nicht näher bezeichneten Teil der Grenze, welche südlich von Brest-Litowsk verlaufen soll. Die Gegenpartei ging von der Ansicht aus, daß die Führung dieser Grenzlinie bestimmt werden sollte durch eine Einigung mit der Delegation der Kiewer Rada. Wir haben seinerzeit erklärt, daß unabhängig von der damals noch nicht klargestellten staatsrechtlichen Stellung der Ukraine keine Rede sein könnte von einer einseitigen Bestimmung der Grenze seitens der Delegation der Kiewer Rada ohne eine vorhergehende Verständigung mit der Delegation der Volkskommissäre. Danach erfolgte die staatsrechtliche Bestimmung des Charakters der Ukrainischen Volksrepublik. Sie ist als Bestandteil in die föderative russische Republik emgetreten. Die Delegationen der Mittelmächte haben entgegen der von ihnen zuerst abgegebenen Erklärung, daß sie sich ihre Stellungnahme gegenüber der endgültigen Anerkennung der internationalen Stellung der Ukraine bis zur Unterzeichnung des Friedensvertrages vorbehalten, sich beeilt, die staatliche Unabhängigkeit der Ukraine gerade in dem Augenblick anzuerkennen, wo die Ukraine formell in den Bestand der russischen Föderation eingetreten ist. Danach sind Ereignisse eingetreten, die von entscheidendem Einfluß hätten sein müssen für die separaten Verhandlungen der Mittelmächte mit der Delegation der Kiewer Rada. Die Rada ist gestürzt unter dem Druck der Sowjets in der Ukraine, wobei ihr Sturz, der schon an sich unvermeidlich war, durch den Umstand beschleunigt worden ist, daß die Rada in ihrem Kampf um die Macht den Versuch gemacht hat, unter Mitwirkung der Mittelmächte mit Gewalt das ukrainische Volk aus dem Bestande der föderativen russischen Republik loszureißen. Wir haben der Gegenpartei offiziell den Sturz der Kiewer

Rada mitgeteilt. Dennoch sind die Verhandlungen mit einer nicht existierenden Regierung fortgesetzt worden. Wir haben der österreichisch-ungarischen Delegation vorgeschlagen, zwar in einem Privatgespräch, aber doch vollständig formell, einen Vertreter in die Ukraine zu entsenden, damit er die Möglichkeit hätte, sich davon zu überzeugen, daß die Kiewer Rada nicht existiert, und daß die Verhandlungen mit ihrer Delegation gar keinen praktischen Sinn mehr haben können. Wir hielten es aber für selbstverständlich, daß, soweit die Delegationen der Mittelmächte eine Nachprüfung dieser Tatsachen nötig hätten, sie jedenfalls die Unterzeichnung eines Friedensvertrages hätten aufschieben müssen bis zur Rückkehr der von ihnen bevollmächtigten Personen. Es wurde uns aber mitgeteilt, daß eine Unterzeichnung des Vertrages keinen Aufschub erleiden könnte. Während daher Verhandlungen mit der Regierung der föderativen russischen Republik geführt wurden, haben die Regierungen der Mittelmächte sich nicht nur beeilt, am 1. Februar entgegen ihrer anfänglichen Erklärung, die Unabhängigkeit der Ukrainischen Republik anzuerkennen, als sie sich eben zu einem Bestandteil des föderativen Rußlands erklärt hatte, sondern haben sich auch jetzt, soweit wir darüber informiert sind, damit beeilt, einen Vertrag zu unterschreiben mit einer Regierung, die gar nicht mehr existiert, wie wir es der Gegenpartei kategorisch erklärt haben. Diese Handlungsweise kann nicht anders als Zweifel hervorrufen, daß die Mittelmächte zu einer Verständigung mit der Regierung des föderativen Rußlands gelangen wollen, und zwar zu friedlichen Beziehungen, die wir jetzt nicht weniger erstreben als zu Beginn unserer Verhandlungen. Noch mehr als das. Die ganze Handlungsweise der Gegenpartei in dieser Frage ruft den Eindruck hervor, als ob die Mittelmächte durch die Anerkennung der Rada in der Person der Rada sich einen Stützpunkt hätten schaffen wollen für die Einmischung in die inneren Angelegenheiten der Ukraine und Rußlands. Selbstverständlich kann es nicht zwei Friedensverträge geben, die ein und dasselbe Gebiet behandeln. Wir erklären daher, daß der vielleicht unterzeichnete Vertrag mit der Kiewer Rada keinerlei Kraft haben kann für das ukrainische Volk und für die Regierung von ganz Rußland. Die Delegation des Rates der Volkskommissäre, zu der offiziell Vertreter des ukrainischen Volkssekretariats gehören, ist die einzige bevollmächtigte und gesetzliche Vertretung der russischen Republik. Nur derjenige Friedensvertrag wird in Kraft sein für die russische föderative Republik und für ihre einzelnen Bestandteile, der, wie wir es hoffen, von unserer Delegation unterschrieben werden wird. Bezüglich der Grenzen bedeutet dies, daß wir diese Frage nur in ihrem ganzen Umfange behandeln können mit Aussicht auf praktischen Erfolg in dieser Frage. Daher möchten wir die Gegen- 
partei bitten, auf unseren Karten die Führung der Grenzlinie zu ergänzen, die uns von Herrn General Hoffmann überreicht worden ist.

Staatssekretär von Kühlmann: Wenn ich auf die ausführlichen Darlegungen des Herrn Vorredners eingehe, so tue ich dies, wie ich im Eingang meiner heutigen Bemerkungen ausgeführt habe, unter sorgfältiger Vermeidung jeder polemischen Absicht. Von diesem Gesichtspunkte aus werde ich auf die historische Übersicht über die gepflogenen Verhandlungen weiter nicht eingehen. Dieselben sind publici juris, und es steht jedermann frei, sich sein eigenes Urteil über diese zu bilden.

Was die Ausführungen des Herrn Volkskommissars für auswärtige Angelgenheiten über das Verhältnis zwischen den Mittelmächten und der Ukrainischen Volksrepublik anbelangt, so ist hierüber nur das zu sagen, daß die uns zugegangenen Nachrichten, an deren Authentizität für uns kein Zweifel besteht, mit den vom Herrn Vorredner uns mitgeteilten Nachrichten in diametralem Widerspruche stehen. Wir müssen selbst die besten Richter darüber sein, welche Staaten wir anzuerkennen für gut befinden und welche nicht. Die Haltung der verbündeten Mittelmächte in dieser Frage ergibt sich klar aus den hier öffentlich abgegebenen Erklärungen, sodaß eine weitere Erläuterung derselben mir nicht nötig erscheint. Die Mittelmächte haben in der Tat mit den Vertretern der Ukrainischen Volksrepublik, die sie ihrerseits anerkannt haben, einen Friedensvertrag abgeschlossen, der das heutige Datum trägt. Die Konsequenzen hieraus ergeben sich für die Mittelmächte ohne weiteres, und ich kann vorläufig, solange die Dinge so stehen, wie sie sind, keine Förderung der praktischen Verhandlungen von einer Erörterung darüber erwarten, welches unsere gegenseitigen Auffassungen der staatsrechtlichen Verhältnisse der Ukraine und ihre rechtmäßigen Vertreter sind.

Zum Schlusse meiner Darlegungen möchte ich kurz auf ein Gebiet eingehen, welches der Herr Vorredner gleichfalls ausführlich behandelt hat, nämlich das zukünftige Ergehen der Völker in den besprochenen Gebieten. Ich beziehe mich hiebei auf die bei den hiesigen Verhandlungen von Vertretern der Mittelmächte abgegebenen sehr ausführlichen Erklärungen sowie auf die Darlegungen, welche über diese Frage von Staatsmännern Deutschlands und der verbündeten oesterreichisch-ungarischen Monarchie vor ihren Volksvertretungen abegegeben woren sind. Trotz der von uns vertretenen und festgehaltenen Auffassung, wonach das Selbstbestimmungsrecht bereits ausgeübt worden ist, sind wir, wie mit Zustimmung des deutschen Reichstages, des auf Grundlage des demokratischesten

Wahlrechtes der Welt gewählten Parlaments, erklärt worden ist, bereit, den planmäßigen Ausbau der bestehenden Vertretungskörper unter entsprechenden Formen zu verbreitern, sodaß sie als tatsächlicher Träger des Volkswillens angesprochen werden können, und eine Kundgebung auf breiter volkstümlicher Grundlage zu ermöglichen. Die Bestimmung des Zeitpunktes und die Form dieser Kundgebung würde zweckmäßig im Einvernehmen mit den derzeitigen Volksvertretungen der betreffenden Gebiete festgesetzt werden.

Minister des Äußern Graf Czernin: Was vorerst die Frage der Existenz der Rada anbelangt, so hat der Herr Vorredner bereits erklärt, daß wir diesbezüglich andere Informationen besitzen als der Herr Vorsitzende der russischen Delegation. Aber ich möchte auch sonst versuchen, durch einige Worte etwas mehr Klarheit in die von dem Herrn Vorsitzenden aufgeworfenen Fragen zu bringen. Wir haben die Regierung der ukrainischen Rada anerkannt, sie ist daher für uns als existierend zu betrachten. Ihr Verhältnis zur Petersburger Regierung ist eine Frage, die uns nichts angeht. Ein unfreundlicher Akt gegen die russische Regierung ist in dem Friedensschlüsse mit der Ukraine nicht gelegen. Wir haben mit der Ukraine kein Bündnis, sondern einen Friedensvertrag unterzeichnet. Die Ukraine ist also für uns durch diesen Vertrag nicht zu einem verbündeten, sondern zu einem neutralen Staat geworden. Kämen wir auch mit der russischen Regierung zu einem Friedensschlüsse, so wird Rußland für uns ebenso zum neutralen Staat werden. Unsere Beziehungen zur Ukraine und unsere Beziehungen zu Rußland werden in diesem. Falle dieselben sein. Ein Unterschied zwischen den beiden würde für uns nur dann bestehen, wenn wir zu keinem Frieden mit dem russischen Rate der Volkskommissäre kämen. Denn in diesem Falle hätten wir die ukrainischen als neutrale, die dem Einflusse des Rates der Volkskommissäre unterstehenden 
Gebiete aber bis auf weiteres als feindliche Gebiete zu betrachten. Das wollen wir eben vermeiden, indem wir unter entsprechenden Bedingungen zu einem Frieden mit Rußland bereit sind. Würden wir dem Wunsche Herrn Trotzkis willfahren und die Rada ignorieren, so würde dies eine Einmischung in die inneren Verhältnisse Rußlands bedeuten, die wir zu vermeiden trachten. Es wäre dies eine Anerkennung dessen, daß die Regierung des Rates der Volkskommissäre die unbestrittene Herrschaft im ganzen ehemaligen russischen Kaiserreiche ausübt. Es ist aber bekannt, daß gewisse Teile dieses Reiches die Herrschaft des Rates der Volkskommissäre nicht anerkennen wollen. Es kann uns nicht zustehen, in diesem Streite, den Rußland innerhalb seiner Grenzen austragen muß, den Schiedsrichter spielen zu wollen. Das wäre unsererseits eine Einmischung. Wir verlangen aber auch nicht, daß der Herr Vorsitzende der russischen Kommission durch seine

Unterschrift die gegenseitige Auffassung bekräftige und erkläre, daß die Autorität des Rates der Volkskommissare nicht im ganzen ehemaligen russischen Kaisserreiche bestehe. Die ganze Schwierigkeit läßt sich umgehen, wenn wir einen eventuellen Vertrag abschließen für die dem Einflusse der Petersburger Regierung unterstehenden Gebiete. Wie weit diese reicht, das zu beruteilen sind wir weder berechtigt noch sind wir dazu imstande. Wir geben zu, daß es kein idealer Zustand ist, wenn wir einen Vertrag schließen müssen, ohne von vornherein bestimmt zu wissen, für welches genau umgrenzte Gebiet er gilt. Dieser Zustand ist aber für uns jedenfalls peinlicher als für die Regierung der russischen Republik. Trotzdem sind wir aber auch unter diesen Verhältnissen dazu bereit, um die Sache des Friedens zu fördern.

Was die Frage des Herrn Vorsitzenden nach dem zukünftigen Schicksal der von uns besetzten Gebiete anbelangt, so verweise ich meinerseits auf meine diesbezüglich öffentlich abgegebenen Erklärungen in der letzten oesterreichischen Delegationssitzung, welche den Herren vielleicht bekannt sind und welchen ich nichts hinzuzufügen habe, nachdem sich in meinem diesbezüglichen Standpunkt nichts geändert hat.

Herr Trotzki: Ich habe leider keine Antwort erhalten auf eine praktische Frage, die ich gestellt hatte. Insoweit jetzt vor uns die Frage der Besprechung der neuen Grenzen von einem neuen bisher hier nicht entwickelten Standpunkte aus, und zwar von der militärisch strategischen Seite auftaucht, müssen wir die Möglichkeit haben, diese neuen Grenzen in ihrem vollen Umfange beurteilen zu können. Selbst wenn wir bedingt auf den Standpunkt des Herrn Grafen Czernin uns stellen würden, was wir materiell gar nicht tun können, so bleibt auch dann natürlich die Möglichkeit, daß nach einer oder zwei Wochen die Gegenpartei wird anerkennen müssen, daß die Macht des Rates der Volkskommissare sich auch auf das Gebiet ausdehnt, in dessen Namen eine Regierung spricht, deren einziges Gebiet Brest-Litowsk bildet, und von diesem Standpunkte aus ist es uns natürlich nicht gleichgültig, wie die Grenze verläuft zwischen dem ukrainischen Teile der föderativen russischen Republik und der oesterreichisch-ungarischen Monarchie. Daher ist es für uns notwendig, eine Vorstellung erhalten zu können von der Grenze in ihrem gesamten Verlauf.

Exzellenz von Kühlmann: Die Grenzfrage kann ich im ganzen dahin beantworten, daß auch hier bei Ziehung der Grenze gesucht worden ist, zwischen der ethnographischen Volksverteilung und den historisch entstandenen Grenzlinien einen verständigen Mittelweg zu finden. Da es sich um eine Angelegenheit der Verbündeten handelt und die uns vorgelegte positive Frage noch nicht Gegenstand der Beratung

der Verbündeten gewesen ist, so kann ich eine kategorische Antwort in der Form, wie sie der Herr Vorsitzende der russischen Delegation wünscht, jetzt nicht geben, bin aber gern bereit, dafür zu wirken, in der von mir vorgeschlagenen Unterkommission die entsprechenden Mitteilungen machen zu lassen.

Minister des Äußern Graf Czernin: Ich möchte hier noch hinzufügen, daß ich ganz auf dem Standpunkte des Herrn Vorredners stehe, daß wir, bevor wir die Frage konkret beantworten, mit unseren Verbündeten Fühlung nehmen müssen, daß ich aber kein vernünftiges Argument sehe, um nach dieser Fühlungnahme die Frage des Herrn Vorsitzenden nicht zu beantworten.

Herr Trotzki: Nachdem hier konstatiert worden ist, daß es keine vernünftigen Rücksichten geben kann, welche uns daran hindern könnten, die Grenze kennen zu lernen, welche für den Teil Rußlands 
geplant ist, der Dank der Entschlossenheit und der Tatkraft der ukrainischen Arbeiter und Bauern unter der Gewalt der ukrainischen Sowjets steht, nehme ich an, daß für die Zusammenstellung einer militärischen Kommission, welche von der Kenntnis der neuen geplanten Grenzen in ihrem vollen Umfange ausgehen wird, keinerlei prinzipielle Einwendungen erhoben werden können.

Staatssekretär von Kühlmann: Ich wäre dem Herrn Vorsitzenden dankbar, wenn er im einzelnen auf meinen Kommissionsvorschlag eingehen wollte. Dann könnten wir uns nach der heutigen Sitzung sofort gegenseitig die Kommissare mitteilen.

Herr Trotzki: Für eine konkrete Antwort auf die mir gestellte Frage müßte ich mich erst mit unserer Delegation besprechen, was wohl selbstverständlich nicht viel Zeit in Anspruch nehmen würde.

Staatssekretär von Kühlmann: Ich nehme also mit Bestimmtheit an, daß ich die Antwort des Herrn Vorsitzenden noch im Laufe des heutigen Abends erhalten kann; denn, wie ich mir vorhin zu bemerken erlaubte, ist es für mich unbedingt nötig, in der für morgen Abend anzusetzenden Sitzung in dieser Frage klarzusehen. Die Herren würden auf diese Weise den ganzen morgigen Tag zur Beratung haben. Unsere Vorschläge sind seit langem bekannt, alle hierauf bezüglichen Momente haben eingehende Erwägung finden können, und glaube, man kann mit vollem Rechte sagen, daß die möglichen Argumente nach allen Seiten abgewogen sind und es sich jetzt darum handelt, Entschlüsse zu fassen.

Von dem Gesichtspunkte der Beschleunigung unserer Verhandlungen aus habe ich einen Teil der heute von uns gemachten Vorschläge in eine Formel gefaßt, welche unter Umständen den zweiten Artikel des zwischen uns zu vereinbarenden Friedens bilden könnte. Ich lese die Formel im Zusammenhange vor:

Rußland nimmt Kenntnis von folgenden territorialen Verände-

rungen, die mit der Ratifikation des gegenwärtigen Friedensvertrages eintreten. Die Gebiete zwischen den Grenzen Deutschlands und Oesterreich-Ungarns in einer Linie, die... verläuft, werden der territorialen Oberhoheit Rußlands nicht mehr unterliegen. Aus ihrer ehemaligen Zugehörigkeit zum russischen Kaiserreiche werden ihnen keinerlei Verpflichtungen gegenüber Rußland erwachsen. Das künftige Schicksal dieser Gebiete wird in dieser Beziehung im Einvernehmen mit ihren Völkern entschieden werden, und zwar nach Maßgabe der Vereinbarung, die Deutschland und Oesterreich-Ungarn mit ihnen treffen werden.

Ich darf dem Herrn Vorsitzenden der russischen Delegation den Entwurf dieser Formel übergeben und möchte im Zusammenhang damit noch sagen, daß der wesentliche Inhalt unseres ersten Vorschlages in Artikel 1, den wir seinerzeit durchdiskutiert haben, eine Diskussion, bei welcher unüberwindliche Schwierigkeiten damals nicht zutagegetreten sind, für uns eine conditio sine qua non eines Friedensschlusses ist. Ich darf den zugrundeliegenden Gedanken dahin präzisieren, daß die Räumung gewisser Gebiete unsererseits zugesagt wurde unter der Bedingung, daß die Räumung der Gebiete unserer Verbündeten gleichzeitig stattfände. Wir haben damals als Zeitpunkt, von welchem an für uns die Räumungsverpflichtung beginnen würde, das Ende der russischen Demobilisierung in Aussicht genommen. Ich stehe aber nicht an, zu erklären, daß wir im Hinblicke auf diesen Zeitpunkt zu Konzessionen bereit wären, wiederhole aber, was ich eben vorhin gesagt habe, daß ein Friedensschluß, in welchem die diplomatische Zusicherung der Räumung der verbündeten Gebiete durch die Truppen der Petersburger Regierung nicht enthalten ist, für uns nicht in Frage käme...

(Schluß der Sitzung 7 Uhr 15 Minuten).

Ugron an das k. u. k. Min. d. Äußern: Über den niederschmetternden Eindruck, den die Abtretung Cholms an die Ukraine auf die poln. Regenten gemacht hat.

Ansuchen um seine Abberufung.

HHSt.A. P.A. 1040 Kr. 56/32 Ausfertigung Auszug 
Telegramm No 134

Herr von Ugron an k. u. k. Ministerium des Äußern Wien. Warschau, 10 Februar 1918.

Chiffre. Geheim.

Antwort auf heutiges Telegramm No. 13 aus Brest-Litowsk.

Ich hatte heute nachmittags mit den Regenten Lubomirski und Ostrowski Aussprache, bei der ich, streng vertraulich und mit Ausdruck betonend, daß ich ohne Auftrag spreche, Mitteilungen vom Inhalte obzitierten gemacht habe. Der Eindruck, den meine Worte hervorgerufen haben, ist nicht zu beschreiben. Beide waren wie niedergeschmettert. Fürst Lubomirski zitterte am ganzen Körper und fand kaum Worte, um seiner Entrüstung Ausdruck zu geben. Er sprach von der vierten Teilung Polens, zu der Oesterreich als Erstes die Hand bot, von der Unaufrichtigkeit und Unverläßlichkeit unserer Politik, daß wir Polen für einige Waggons Getreide verkauft haben etc. Viel ruhiger, aber nicht weniger scharf drückte sich Herr von Ostrowski aus. Er meinte, daß dieser Friedensschluß nicht bestehen könne, sie würden dagegen vor den Neutralen und der ganzen Welt protestieren und das letzte Wort wird die Konferenz sagen, an die sie appellieren werden.

Ich trat natürlich diesen Angriffen entgegen und suchte meine aufgeregten Mitredner zu beschwichtigen und führte im Sinne der erhaltenen Weisungen die katastrophalen Ernährungsverhältnisse, die subversiven Strömungen im Hinterlande etc. etc. an und sprach von den beruhigenden Ergebnissen der Berliner Besprechungen, worauf ich die Antwort erhielt, daß, wen wir im Osten der besiegten Ukraine gegenüber nachgeben haben müssen, werden wir gewiß mit unseren Wünschen betreffend die Westgrenze den übermächtigen Deutschen gegenüber nicht durchdringen können... Ich befürchte, daß unter diesen Umständen nun die austro-polnische Frage auf längere Zeit ganz außer Kombination kommt und

wir nunmehr eine andere Politik werden befolgen müssen. Ich bin aber mit der bis jetzt befolgten Richtung ganz verwachsen; ich habe für die austro-polnische Lösung und speziell die Personalunion seit Monaten mit ganzer Hingebung, mit meinem ganzen Können gewirkt und auch entschiedene Erfolge erreicht. Eine andere Politik kann ich hier nicht vertreten und diese hat nunmehr hier wenig Aussicht auf Erfolg. Deshalb bitte ich Euer Exzellenz, mich in absehbarer Zeit von meinem hiesigen Posten abberufen zu wollen.

Gleichlautend sub 62 Brest.

Lublin, 11. Februar 1918

Hoenning an Czernin: Bericht über die poln. Reaktion auf den Brester Friedensvertrag sowie über die zu treffenden Maßnahmen.

$$
\text { HHSt.A. P.A. } 1040 \text { Kr. 56/32 a Ausfertigung - Auszug }
$$

Stimmung nach dem Friedensschluss.

Lublin, 11. Februar 1918.

Baron Hoenning an Grafen Czernin Wien.

Geheim!

$\mathrm{Zu}$ keiner Weitergabe geeignet.

Das Telgraphen-Korrespondenz-Bureau hat die Depesche mit dem Auszuge des Friedensvertrages mit der Ukraine heute früh erhalten, mir wurde der Inhalt um $10 \mathrm{Uhr}$ vormittags bekannt und schon um 1/2 12 Uhr vormittags ersuchte mich Graf Szeptycki, zu ihm zu kommen, da er gerade die Abordnung der polnischen Wirtschaftszentrale empfangen hatte, die von der auch ihr zu Ohren gekommenen Nachricht bestürzt, zum Generalgouverneur geeilt war und ihn in verzweifelter Stimmung mit Fragen bestürmte.

Auf die Bestätigung der Abtretung des gesamten ehemaligen Chelmer Gouvernements hin erklärten die Herren ihre Stellen sofort niederzulegen, da sie einen solchen Schlag wohl von Deutschland, nie aber von Oesterreich-Ungarn erwartet hätten... 
... Der Gouverneur schien von dieser Szene tief erschüttert und erklärte mir, daß es ihm ganz unmöglich sei, in der nächsten Zeit auf seinem Posten zu verbleiben, da er sich als k. u. k. Offizier und Pole den Leuten gegenüber zu tief mit seiner Ehre verpfändet habe...

... Die allzu zahlreichen k. k. Beamten und k. u. k. Offiziere polni-

scher Nationalität benehmen sich zum Teile nicht ganz einwandfrei, einige schüren sogar...

... Für mich besteht kein Zweifel, dass wir sofort mit einer teilweisen Entpolonisierung des höheren und mittleren Verwaltungsapparates einsetzen müssen, denn vorläufig handelt es sich um sofortiges Niederschlagen aller Unruhen und Angriffe, um die wichtigsten Interessen des Hinterlandes, um Ruhe und Ordnung.

Das Verbot, anlässlich der Besprechungen der Friedensbedingungen in der Presse uns feindliche oder verächtlich machende Artikel zu veröffentlichen, habe ich im Wege des Pressechefs heute erlassen...

Hoenning

Lublin, Ohne Datum

Szeptycki an das k. u. k. Min. d. Äußern: Über große Erbitterung der poln. Öffentlichkeit wegen der Abtretung Cholms an die Ukraine sowie Ansuchen um seine Enthebung vom Posten des k. u. k. Militärgouverneurs.

HHSt.A. P.A. 1040 Kr. 56/32 a Ausfertigung

Telegramm No Präs. 2135/18

Graf Szeptycki an k. u. k. Ministerium des Äußern. Lublin (ohne Aufgabedatum) 1918.

Die Veröffentlichung der im Friedensvertrag erfolgten Abtretung des alten Chelmer Gouvernements an die Ukraina hat in der polnischen Bevölkerung des Okkupationsgebietes allgemeine Konsternation und helle Verzweiflung gepaart mit großer Erbitterung ausgelöst, die von politisch schwerwiegenden Konsequenzen bereits begleitet erscheint. Das mir bisher von den autonomen Organisationen sowie von den daran mitwirkenden Persönlichkeiten entgegengebrachte Vertrauen hat augenscheinlich eine wesentliche Einbuße erlitten. Der Landwirtschaftsrat hat seine Tätigkeit eingestellt, weitere Entschließungen sollen heute in einer Plenarsitzung erfolgen. Diesbezüglich werde ich abgesondert berichten. Zahlreiche Nachrichten weisen auf bevorstehende Protestmanifestationen, die den Charakter von ernsten Unruhen annehmen können. Ich habe bereits mit Bericht des Delegierten der Militärverwaltung in Warschau No. 41... (Worte fehlen). Nachdem ich durch neun Monate für die austropolnische Lösung gearbeitet habe und dieselbe heute ganz ausgeschlossen ist, ist meine sofortige Enthebung vom Posten des Militärgeneralgouverneurs eine politische und militärische Notwendigkeit geworden. Ich bitte daher erneuert, meine sofortige Enthebung vom Posten des Militärgouverneurs bei Seiner Majestät zu beantragen.

Geht an Armeeoberkommando, Chef des Generalstabes und zur Kenntnis an das Ministerium des Aeußern.

Trauttmansdorff an Burián: Übersendung der Broschüre: „Ist Cholmerland polnisch oder ukrainisch?" von Georg von Gassenko.

HHSt.A. P.A. 1040 Kr. 56/32 a Druckschrift 
Nr. 29.433

Baden, am 9. Mai 1918.

Broschüre „Ist Cholmerland polnisch

oder ukrainisch" von Georg von Gassenko.

1 Beilage.

Graf Trauttmansdorff an Baron Burián von Rajecz.

Ich beehre mich, Euer Exzellenz anverwahrt eine vom k. u. k. Militärattache in Bern in Vorlage gebrachte Broschüre über die Cholmerfrage, die zum Verfasser einen gewissen Georg von Gassenko hat, zu unterbreiten.

Gassenko ist angeblich Kommissär der wirtschaftlichen Angelegenheiten für die Ukraine in der Schweiz.

Da mir die Nachrichtenabteilung diese Broschüre nur für kurze Zeit überlassen hat, darf ich Euer Exzellenz um eine baldige Rückleitung derselben bitten. Trauttmansdorff.

Georg v. Gassenko. Broschüre, zu beziehen durch Librairie des Nationalités Rue Caroline, Ancienne, 2 Lausanne 1918.

\section{Ist Cholmland polnisch oder ukrainisch?}

Die heftige Unzufriedenheit der Polen, welche durch den Frieden von Brest-Litowsk hervorgerufen wurde, ist nur durch ihren unglückseligen Imperialismus erklärlich, der sich mit den ethnographischen Grenzen Polens nicht begnügen will.

Von polnischer Seite verlauten Beschuldigungen gegen die Bestimmung der Westgrenze mit der Ukraine, als ob eine vierte Teilung Polens stattgefunden hätte.

Die Geschichte kennt nicht nur Teilungen Polens, sondern auch der Ukraine, und zwar zugunsten jenes. Zusammen mit Galizien wo die Polen herrschen, würden ihnen etwa vier Millionen Ukrainer zufallen. Die Polen wendeten überhaupt ein seltsames Verfahren an, indem sie oft unter ,polnisch“ lediglich das, was katholisch ist, verstünden, während es doch auch unter den Ukrainern Katholiken gibt; sie appellierten ferner an ihre ,historischen Rechte“, die im Laufe der Geschichte längst verwirkt wurden und heute keine Grundlage mehr für die Politik der Staaten bieten. Übrigens ist bereits in Brest-Litowsk ein Plebiszit im Cholmland in Aussicht genommen worden und die Ukrainer sehen den Ergebnissen der Volksabstimmung ruhig entgegen. Die polnischen Statistiken würden dieser Probe nicht standhalten; auch was eine Statistik des deutschen Oberkommando Ost anlangt, die zugunsten der Polen ausfiel, konnte der Delegierte der Republik Ukraine Georg v. Gassenko bei seiner Anwesenheit in Brest-Litwosk feststellen, daß sie vorwiegend unter Heranziehung lokaler polnischer Hilfskräfte zustandegekommen sei.

Das Cholmland ist ukrainisch. Es ist das klassische Land der Verfolgung der Uniaten und jeder Pole weiss, daß die Uniaten, durch ihre Rasse, wie durch ihre Religion Ukrainer sind.

Die russische Regierung, die weder die uniatische Religion, noch die ukrainische Nationalität anerkannte, behandelte sie als aufrührerische Russen. Nach schrecklichen Verfolgungen, Erschiessungen und Ertränkungen, nach fast einem Jahrhundert solcher Praktiken, welche Europa empört haben, gab endlich die russische Regierung zu, daß die Unglücklichen, die ihrem Glauben treu geblieben waren, katholisch bleiben durften, aber nach lateinischem Ritus. Sie wurden durch den polnischen Klerus, welcher sich mit den Zivilregistern beschäftigt, als Polen eingeschrieben, während die orthodoxen Ukrainer durch die Popen als Russen eingetragen wurden. Es war in kleinem Umfange die Lösung der Ukraine-Frage, so wie sie von den russischen und polnischen Nationalisten im allgemeinem geträumt wurde.

Dabei waren diese Gebiete durch ihre Lage an der Grenze zwischen Ukraine und Polen natürlich einer stärkeren Polonisierung ausgesetzt.

Die derzeitige Grenze scheidet die östlichen ukrainischen Teile von den polnischen (westlichen) Teilen der Distrikte und gibt sogar Polen ukrainische Gebiete gegen Siedletz, während sie nicht ein Zoll breit polnischen Landes der Ukraine gibt. Es genügt einen Blick auf irgend eine ethnographische Karte zu werfen, um sich davon zu überzeugen. Alle polnischen Behauptungen können keiner Kritik standhalten und es scheint, dass die polnische Aufregung die Cholmer Angelegenheit nur zu dem 
Zwecke ausgenützt hat, um einer längst hingestellten und gegen die Zentralmächte gerichteten Stimmung eine entsprechende Lösung zu geben.

Wenn wir uns an die vom Wiener Kongress, der nur Irrtümer und Ungerechtigkeiten geschaffen hat, gefassten Entschlüsse halten müssten, wie es die Polen machen, konnte Krakau nie wieder Polen angehören. Übrigens, trotz polnischer Behauptungen die mit dem Verdrehen der Geschichte grenzen, wurde auf dem Wienerkongress kein Wort über Cholmland gesprochen, was uns die Protokolle von jenen beweisen.

Cholm und Pidlasche sind auf die barbarste Weise geräumt worden, auf Befehl des Großfürsten Nikolaus. Die Güter der Flüchtlinge sind durch die österreichische Behörde, die damals sehr polonophile war, polnischen Kolonisten gegeben worden. Eine intensive Polonisierung des Landes durch das absolute Verbot ukrainische Schulen zu eröffnen und die Errichtung hunderter polnischer Schulen, bezeugte, was die Intensionen der Polen waren.

Weder historisch, noch ethnographisch, kann man die polnische „Empörung“ rechtfertigen. In historischer Hinsicht erscheint die Sache folgendermassen.

\section{Die Geschichte.}

Der mächtigste Herrscher des alten ukrainischen Kiewer Staates war im X. Jahrhundert der Großfürst Wolodymyr der Grosse, dem alle alten ukrainischen Fürstentümer unterworfen waren. $\mathrm{Zu}$ der Zeit existierte schon das Cholmland und ebenfalls Pidlasche als Teil des Kiewer Staates. In kirchlichreligiöser Abhängigkeit gehörte das Cholmland zur Diözese von Wolodymyr in Wolynien und Pidlasche zu derjenigen von Turiw. Als Grenze zwischen Polen und dem alten Kiewer Staate diente die Weichsel, damals Bila Woda genannt. Zwar überschritt der polnische König Boleslas der Tapfere die Weichsel im Jahre 1018 und nahm von den Lublin- und Cholmländer Besitz, der jedoch nur 12 Jahre dauerte, denn schon im XI. Jahrhundert eroberte es der Kiewer Großfürst, Jaroslav der Weise, dem Kiewer Staate zurück und seit der Zeit gehörte diese Gegend dem ukrainischen Staate bis zur Mitte des XIV. Jahrhunderts, wo einige Veränderungen stattfanden. Bei dem Falle von Kiew, welcher durch den Überfall der Tataren-Horden bestimmt war, rückte das Zentrum des staatlichen Lebens der altukrainischen Länder mehr gegen Westen (und das russische Zentrum nach Osten) und zwar nach Halytsch auf dem Dnistro (im jetzigen Galizien), wo der ukrainische König Danylo ein mächtiges Königreich in der ersten Hälfte des XIII. Jahrhunderts gründete. Es gehörten auch das Cholmland und Pidlasche dazu und der obengenannte altukrainische Fürst, den der päpstliche Legat Opis in Drohytschyny im Jahre 1253 krönte, war derselbe, welcher die Städte von Uhrowsk und Cholm gründete. Nach seiner Krönung verlegte er seine Hauptstadt nach Cholm.

Diese Länder wurden im Jahre 1352 von dem polnischen König Kasimir den Grossen erobert, aber auch dann wurden sie nicht mit Polen vereinigt, sondern mit der sogenannten ,ruthenischen Wojewodschaft", in der Einsicht, daß diese Gebiete nicht zu Polen gehören und daß man sie als fremdes ukrainisches Land betrachten muss. So waren diese Länder nie mit Polen vereint und erst Napoleon zählte sie zu dem von ihm in 1809 gegründeten Warschauer Fürstentum. Diese Sachlage blieb auch in Wiener Kongress in 1815 bestehen, als das sogenannte polnische Königreich, besser gesagt KongressPolen dem russischen Staate zugeteilt wurde. Die russische Regierung liess lange Zeit das Gouvernement unverändert und nur in 1910 machte sie aus dem Cholmlande ein eigentliches Gouvernement, wie bekannt mit der geheimen Zustimmung der polnischen Vertreter in der Staatsduma. Um sie zu beruhigen wurde ihnen von der Regierung Stolypins die lokale Selbstverwaltung im polnischen Königreich versprochen. Die Polen waren vollständig einverstanden mit einer solchen Lösung der Cholmer Angelegenheit. Es ist daher ganz unverständlich wie die Polen sich auf Zuwiderhandlung gegen ihre geschichtlichen Rechte berufen können und noch weniger begreiflich ist es, wenn sie sich auf die ethnographischen Beziehungen in dieser Gegend berufen.

\section{Die Ethnographie.}

Nach der offiziellen russischen Statistik (gegen welche sich nie ein polnischer Protest erhoben hat) zählte die Bevölkerung im Cholmland und Pidlasche rund 1,800.000 Einwohner. Der Prozentsatz nach 
Nationalitäten — nach der offiziellen Zählung von 1909, die als Hauptgrund zu der Absonderung des Cholmlandes in ein eigentliches Gouvernement diente - ist folgender:

a) Das Cholmland.

$\begin{array}{lrrl}\quad \text { Distrikte } & \text { Ukrainer } & \text { Polen } & \text { Juden } \\ \text { 1. Cholm } & 48.16 \% & 28.56 \% & 10.94 \% \\ \text { 2. Konstantiniw } & 70.82 \% & 14.20 \% & 14.94 \% \\ \text { 3. Bila } & 60.48 \% & 15.69 \% & 23.35 \% \\ \text { 4. Wolodawa } & 64.97 \% & 14.80 \% & 15.52 \% \\ \text { 5. Hrubeschiw } & 57.31 \% & 25.91 \% & 16.22 \% \\ \text { 6. Tomaschiw } & 46.71 \% & 41.07 \% & 12.22 \% \\ \text { 7. Samostje } & 29.01 \% & 52.36 \% & 18.08 \% \\ \text { 8. Bilhoraj } & 38.56 \% & 49.00 \% & 11.43 \%\end{array}$

b) Pidlasche.

$\begin{array}{lrrr}\text { 1. Bilsk } & 39.11 \% & 34.85 \% & 14.92 \% \\ \text { 2. Beresjtje } & 64.38 \% & 3.89 \% & 20.79 \% \\ \text { 3. Kobryn } & 79.57 \% & 2.22 \% & 13.71 \%\end{array}$

Wie sich nach dieser Statistik herausstellt, haben die Polen in der ganzen Gegend nur in zwei Distrikten, nämlich Zamostje und Bilhoraj, eine kleine absolute, richtiger gesagt relative Majorität, während die Ukrainer in allen, ausser diesen zwei, die absolute Majorität haben. Im Vertrage von Berestjtje-Lytowsjkje ist die Grenze des ukrainischen Staates nicht einmal so weit bestimmt, denn die polnischen westlichen Teile sind abgeschnitten worden und sogar noch mehr; ausserdem ist die Bedingung enthalten, daß die Ausschliessung einzelner Grenzorte durch die Rechte einer speziellen Grenzkommission, der auch Polen angehören werden, gesichert ist. Dabei sollen die Wünsche der lokalen Bewohner berücksichtigt werden.

Die Polen berufen sich auf die schon während der Okkupation stattgehabte Zählung, aber wie diese gemacht wurde, ist allen bekannt. Oben- stehend wurde auf den Teil des Interview mit Herrn Georg von Gassenko (in der „Neuen Zürcher Zeitung“ Nr. 385 vom 20. III.) hingewiesen, welcher deutlich die Quelle dieser Statistik zeigt und ausserdem muß noch gesagt werden, daß die ukrainische Bevölkerung teils weggejagt wurde, teils von den Russen genommen (bekannt als die sogenannten „,cholmischen Flüchtlinge“). Sogar hat der Generalgouverneur von Lublin, Graf Scheptyzj-

kyj (nicht zu verwechseln mit dem ukrainischen Patrioten, dem Metro- politien Grafen Andrij Scheptyzjkyj) kürzlich offen gesagt, daß alles mögliche gemacht worden war, um das Gebiet als ,polnisch“ dem „Königreiche“ Polen anzuschliessen. Was aber am merkwürdigsten ist, ist, daß die protestierenden Polen sich auf die Zahl der Katholiken stützen, als ob sie die Zahl der Polen wäre. Auf dieser Bezeichnung begründen sich wahre politische Machinationen. Die Cholmer Ukrainer gehörten zu der griechisch-katholischen, d. h. uniatischen Kirche (welche, wie bekannt, eine Besonderheit der Ukrainer ist). Als die russische Regierung die uniatische Religion in Russland verbot, und nachdem die Ukrainer nicht orthodox werden und sich nicht Moskau unterwerfen wollten, gingen sie zum römischen Katholizismus über. Die ukrainische Kirche ist aber noch im ukrainischen Teil Galiziens aufrecht erhalten geblieben, wo sie als die nationale Kirche der ukrainischen Bevölkerung gilt. Es ist also klar, daß die Katholiken im Cholmland nicht nur aus diesem Grunde als Polen gerechnet werden müssen - so wie die Protestanten-Tschechen nicht als Deutsche, die muselmännischen Georgier in Lasistan als Türken und die orthodoxen Rumänen nicht als Russen gezählt werden können. Der ukrainische katholische Metropolit Graf A. Scheptyzjkyj hat im österreichischen Herrenhause energisch eben gegen dieses polnische „Verdrehungsspiel“" mit dem Katholizismus protestiert.

Nicht nur russische und ukrainische Gelehrte, sondern auch die Tschechen, welche der ukrainischen Bewegung im allgemeinen feindlich gegenüberstehen, betrachten das Land als ausdrücklich ukrainisch. So zum Beispiel der grosse Gelehrte und tschechische Patriot Safaryk in seinem Werke „Slowansky narodopis“ (1842) bezeichnet als Grenze zwischen Ukrainern und Polen genau dieselbe, welche wir im Vertrage von Brest-Litowsk finden. Wir wollen nicht von den deutschen Ethnographen sprechen wie Rittich (1878) oder russischen wie Florinski, aber unter den Tschechen haben wir noch den Professor Niederlé, welcher auf seiner Karte (in der „Enzyclopédie der slawischen Philologie“ 
1909) mit Mezyretsche, Radyn, Krasnostaw, Samosjtje, Tarnohrad, die Grenze zwischen den beiden Nationalitäten angibt, genau wie im gegenwärtigen Friedensvertrag.

Es ist recht merkwürdig das Entrüstungsgeschrei zu vernehmen, das sich bei dem Rückfall von Cholm mit einigen Zehntausend Polen an die Ukraine erhoben hat, während die Annexion seinerzeit durch die Zentralmächte Galiziens an Polen mit ihren vier Millionen Ukrainern und ohne sie zu befragen - von allen mit Stillschweigen übergangen wurde.

Die offenbare Böswilligkeit und die notorische Ungerechtigkeit der Presse, welche unter dem Einflusse der Feinde der Ukraine steht, sind übrigens nicht eine Spezialität der ententistischen Presse. Die Gesamtheit der deutschen Presse, von der russophilen „Kreuzzeitung“ zu der polonophilen „Germania“, zu den „Berliner Tagblatt“, „Voss'sche“ und „Frank-

furter Zeitung" usw., ist uns bis zu der letzten Zeit feindlich gesinnt gewesen.

Die Ereignisse haben ihren Lauf genommen und alle diese Insinuationen und Invektiven haben sie nicht daran hindern können. Oesterreich und Deutschland beginnen bereits die Wichtigkeit der Ukraine zu begreifen. Die Entente wird sie später — zu spät vielleicht — begreifen, obwohl die französische Diplomatie hellseherischer ist als die Presse.

Indem die Presse die chimärischen Forderungen des polnischen Imperialismus unterstützt, leistet sie der polnischen Sache einen schlechten Dienst. Kein Übereinkommen wird zwischen uns möglich sein, solange Polen nicht auf ihre Absichten auf unsere Gebiete verzichtet haben wird. „Jeder bleibe bei sich!" soll der Wahlspruch derer sein, die in guter Nachbarschaft leben wollen. Es gibt in Ukraine und Lithauen grosse polnische Gutsbesitzer, die eine kleine Anzahl polnischer Kolonisten mitgebracht haben. Vergessen wir nicht, dass die mehr oder weniger adlige Herrschaft vorüber ist und das kein Grund ist um glauben machen zu wollen, daß Jitomir nach Cholm und sogar Mohilew am Dnieper polnisch sind.

Gewisse Freunde von Gross-Polen begnügen sich mit Lemberg und Wilna - die Hauptstädte Galiziens und Lithauens, weil sie eine scheinbare Majorität polnischer Einwohner angeben. Wahrheitsgemäss gehört die Majorität in allen Städten der Ukraine, Lithauens und sogar Polens den Juden, die sich gewöhnlich an die herrschende Nationalität halten. Man spricht viel polnisch in diesen zwei Städten, wie französisch in Genf und in Brüssel, was kein Grund ist damit Frankreich sie fordert, oder Deutschland sich Lodz in Polen annektiert, weil dort Deutsch gesprochen wird.

Man muss der Wahrheit ins Gesicht sehen und sich keinen Chimären hingeben. Polen hat nicht mehr Rechte auf die Ukraine oder deren Gebiete als Deutschland oder Russland auf Polen. Diejenigen welche diese Fragen unlösbar finden, wollen es entweder nicht zugeben oder leben nicht in der Wirklichkeit. Die „Balkanen vom Norden“ können deutschen oder französischen Publizisten missfallen, sie existieren nicht destoweniger und es ist ja doch unmöglich zur grossen Türkei zurückzukehren, um die Frage zu vereinfachen.

Polen soll sich zufrieden geben, frei zu sein und nicht versuchen über andere zu herrschen. Nur dann wird es seinen rechten Platz in der freien Konfederation der Völker einnehmen können.

Die Quellen:

a) Graf M. Tyszkiewicz „Ukraine et Pologne“, Journal de Genève, No 54, du 24 février.

b) Wistnyk, No 8, page 113 .

c) Interview mit H. G. v. Gassenko. N. Z. Z., No 385, vom 20. März.

\section{References}

1.Hornykiewicz T. (1967), Aus dem Inhalt des II. Bandes, Events in Ukraine 1914-1922 their importance and historical background, Publications of the W. K. Lypynsky east european research institute, Philadelphia, Vol. II, pp. XXXI-XLVIII.

2. Hornykiewicz T. (1967), Events in Ukraine 1914-1922 their importance and historical background, Publications of the W. K. Lypynsky east european research institute, Philadelphia, Vol. II. 